Sosyo

Ekonomi

January-June

2014-1

\title{
Türkiye İmalat Sanayi Sektörlerinin İhracatı - Zaman Serisi Analizi
}

Güzin BAYAR

Selman TOKPUNAR

guzinbayar@yahoo.com

selmantokpunar@gmail.com

\section{Turkish Manufacturing Industry Sectors' Exports - A Time Series Analysis}

\begin{abstract}
In this study, Turkey's export by manufacturing industry sectors was analysed. For this purpose, quarterly data between 1998q1-2012q1 for the first 4 highest exporting sectors within ISIC Rev. 3. two digit manufacturing industry sectors was used; namely, basic metal, motor vehicles, textile and clothing sectors. Long term and short term relationships between the variables were investigated using fully modified ordinary least squares (FMOLS) and vector error correction (VEC) models. Model results show that foreign economic activity is the most important factor affecting exports of all four sectors. Increase in unit labor costs; adversely affect exports of clothing and motor vehicle sectors in the long run. Increases in unit export prices have increasing effect in all sectors except textiles. Real appreciation of Turkish Lira adversely affect only textile sector among the four.
\end{abstract}

Keywords $\quad$ : Exports, Time Series, Sectors, VEC, FMOLS.

JEL Classification Codes : $\quad$ C22, F14.

Özet

Bu çalışmada Türkiye'nin ihracatı sektörler bazında analiz edilmiştir. ISIC Rev. 3 iki basamaklı bazda 22 imalat sanayi sektöründen en çok ihracatı yapılan ilk 4 sektörün (ana metal, motorlu kara taşıtları, tekstil ve giyim sektörleri) 1998-2012 yılları arasında çeyrekler itibariyle zaman serisi denklemleri kurularak değişkenler arasındaki uzun ve kısa dönemli ilişkiler tamamen değiştirilmiş en küçük kareler (Fully Modified Ordinary Least Squares-FMOLS) ve vektör hata düzeltme (Vector Error Correction-VEC) yöntemiyle araştırılmıştır. Regresyon sonuçlarına göre, incelenen sektörlerin tamamında ihracatını etkileyen en önemli değişkenin dış talep olduğu görülmektedir. Birim işgücü maliyetlerinin artması Giyim Eşyası ve Motorlu Kara Taşıtları sektörlerinin ihracatını uzun dönemde olumsuz olarak etkilemektedir. İhracat birim fiyatlarındaki artışlar tekstil sektörü hariç tüm sektörlerde ihracat gelirlerini artırıcı etkide bulunmaktadır. Reel kur değerlenmesinden incelenen sektörler içinde sadece tekstil sektörü olumsuz etkilenmektedir. 
Güzin BAYAR \& Selman TOKPUNAR 


\section{Giriş}

Günümüz dünyasında ülkelerin sadece iç pazara üretim yapan sanayi yapılarıyla kalkınması imkânı kalmamıştır. Üretilen ürünlerin uluslararası rekabet gücüne sahip olması kalkınmış ülke olmanın başlıca şartlarından biridir. İhracat, GSYH'nin önemli bir bileşeni, pek çok ülke için sanayi üretiminin ve büyümenin itici gücüdür.

İhracat, özellikle Türkiye gibi ihracata dayalı kalkınma stratejisini benimseyen ülkeler için daha da önemlidir. Türkiye, 1980 yılından itibaren dış ticaretini liberalleştirmiş ve ihracata dayalı kalkınma stratejisini benimsemiştir. Bu dönemden itibaren Türkiye'nin dış ticareti çok yüksek oranlarda artmıştır. 1980 yılında 2,9 milyar dolar olan ihracat 2008 yılında 132 milyar dolara kadar çıkmıştır. Bu rakam, yıllık ortalama \%15,5 artış anlamına gelmektedir. 2009 yılında küresel krizin etkisiyle toplam ihracat 102 milyar dolara inmiştir. 2010 yılında krizden çıkılmaya başlanmasıyla ihracat da artış göstermiştir; 2010 yılında ihracat 2009 yılına göre \%11,5 artış göstererek 113,9 milyar dolar seviyesinde, 2011 yılında bir önceki yıla göre \%13,6 oranında artarak 135 milyar dolar seviyesinde ve 2012 yılında ise, \%18,5 artışla 152,5 milyar dolar seviyesinde gerçekleşmiştir.

Türkiye'nin dışa açılmaya başladığı 1980 yılında sanayi ürünlerinin toplam ihracat içindeki payı sadece \%36 iken; 2011 yılında toplam ihracatın \%93,4’ü imalat sanayi ürünlerinden oluşmuştur.

Bu çalışmanın amacı Türkiye için büyük öneme sahip imalat sanayi ihracatını belirleyen faktörleri alt sektörler itibariyle incelemektir. $\mathrm{Bu}$ amaçla ISIC Rev 3. iki basamaklı sektörlerden, Türkiye'nin ihracatında en yüksek paya sahip ilk dört sektör için, 1998Ç1-2012Ç1 dönemini kapsayan çeyreklik verilerden oluşan veri seti oluşturulmuş ve söz konusu sektörlerin ihracatının Tamamen Değiştirilmiş En Küçük Kareler (Fully Modified Ordinary Least Squares (FMOLS)) ve Vektör Hata Düzeltme (Vector Error Correction-VEC) Modeli çerçevesinde tahminleri yapılmıştır.

Çalışmanın 2. bölümünde konu ile ilgili literatüre yer verilmekte, 3. bölümde veriler ve yöntem açıklanmakta, 4. bölümde regresyon sonuçlarına ve 5. bölümde değerlendirmelere yer verilmektedir.

\section{Literatür Taraması}

Ekonomi literatürü dış ticaret denklemleri açısından çok geniştir. Bu sebeple bu bölümde öncelikle konu hakkında birkaç önemli uluslararası çalışmaya değinildikten sonra Türkiye'nin ihracatını inceleyen çalışmalara ağırlık verilecektir. 


\subsection{Uluslararası Çalışmalar}

İhracat modelleri temelde iki grupta incelenmektedir: tam ikamesi mümkün olan malların ihracatı ve eksik ikame edilebilen malların ihracatı. Alüminyum, bakır, pamuk, şeker gibi hammaddeler tam ikamesi mümkün olan mallardır. Bu mallar için dünyada tam rekabet piyasasına yakın bir durum mevcut olup, dünya piyasalarında tek bir fiyat belirlenmektedir. İhracat denklemleri hakkındaki literatür çoğunlukla eksik ikame edilebilen mallar için yapılmaktadır. Yerli ve yabancı malların nitelikleri ve fiyatları arasında farklılıklar olmakta ve yurt dışından ithal edilen malların yerli olarak üretilen malları tam olarak ikame etmesi (veya tersi) genellikle mümkün olmamaktadır. King (1997), ihracat arz ve talep denklemlerinin teorik alt yapısını tartışmakta, bu konuda kapsamlı bir literatür taraması vermektedir. Bir başka literatür taraması makalesi Goldstein ve Khan (1985) ise diş ticarette gelir ve fiyat etkilerine ilişkin literatür taramasında konu ile ilgili çalışmaların bir özetini vermekte, ticaret modellemesinde kullanılan ekonometrik modelleme yöntemlerini etkili bir şekilde tartışmaktadır.

İhracat talep denklemleri bağımlı değişken ihracat olmak üzere, bağımsız değişkenler olarak genellikle bir fiyat rekabetçiliği göstergesi (reel kur, ihracat birim fiyatları, göreli fiyatlar, kur volatilitesi gibi) ve dış talep göstergesinden (ticaret ortaklarının GSYH's1, ticaret ortaklarının sanayi üretim endeksi, dünya geliri vb.) oluşur. İhracat talep denklemlerinin zımni varsayımı, ihracatın arz esnekliğinin sonsuz olduğu, talep bulunduğu sürece talebi karşılayacak üretimin yapılacağıdır. Çeşitli ülkelerin ihracat talep denklemini kuran çalışmalar arasında Warner ve Kreinin (1983), Senhadji ve Montenegro (1998), Achy ve Sekkat (2003), Harb (2007), Lehman vd. (2007), Kumar (2009), Jassaud ve Rey (2009), Kumar (2009), Pineres ve Jorda (2010), Bourdon ve Korinek (2011) sayılabilir.

Diğer taraftan, ihracat arz denklemleri, üretim olmadan ihracat olamayacağından hareketle, ihracatı üretim yönünden incelemekte, bağımsız değişkenler olarak fiyat göstergelerinin yanısıra, birim iş gücü maliyetleri, çalışma standartları, ücretler, verimlilik, firma özellikleri, iç talep, ihracat teşvikleri, vergiler, sermaye/üretim oranları, doğrudan yabancı yatırımlar gibi arzı etkileyen değişkenleri modelde içermektedir (Rodriguez ve Samy (2003), Manez vd. (2004), Mah (2007), Bonnal (2010), İbrahim (2011)).

İhracat talep denklemlerinin ihracatı etkileyen arz yanlı faktörleri göz ardı etmesi ve ihracat arz denklemlerinin de ihracat üzerinde etkili olan talep yanlı faktörleri dışlaması sebebiyle "dışlanmış değişken sapması"na (omitted variable bias) ve denklemdeki fiyat değişkeninin endojenliği sebebiyle "eş anlılık sapması"na (simultaneity bias) yol açtığına dair eleştiriler bulunmaktadır. $\mathrm{Bu}$ sorunlardan dışlanmış değişken sapmasını gidermek üzere ihracat belirleme modelleri kurulmaktadır (King, 1997). İhracat belirleme modellerinde ihracat talep denklemine karlılık, vergiler, teşvikler, iç talep baskısı, maliyetler gibi arz yanlı değişkenler de eklenerek dışlanmış değişken sapmasının 
azaltılması hedeflenmektedir ((Egert ve Zurnaquaro (2008), Utkulu and Seymen (2004), Dinçer ve Kandil (2011), Chen vd. (2011)). Bu makalede de ihracat belirleme modeli yaklaşımı benimsenmektedir.

İhracat denklemlerindeki eşanlılık sapmasını gidermek üzere ise ihracat arzı ve ihracat talebinden oluşan iki denklemin eşanlı denklem sistemi ile çözülmesine dayalı modeller geliştirilmiştir; dengede ihracat arzı ihracat talebine eşit olacaktır ve ihracat fiyatları endojen olarak (sistem içinde) belirlenecektir (King, 1997). Ayrıca, yazarın iki rejim modelleri olarak adlandırdığı, ihracat talep ve arz denklemlerinin bir bileşimini veren modeller bulunmaktadır. Bu modeller çoğunlukla, konjonktüre, pazarın durumuna ve firma seviyesindeki farklılıklara göre ihracat için arz veya talep yönlerinden hangisinin ağır bastığını belirleyerek tahminde bulunmaya dayanmaktadır. Eşanlı denklem kurarak tahmin yapan çalışmalar arasında Arize (1987), Aslan and Wijnbergen (1993), Rahmaddi and Ichihashi (2012) sayılabilir.

\subsection{Türkiye'yi İnceleyen Çalışmalar}

Türkiye'nin ihracat yapısı ve ihracatı etkileyen faktörler dışa açılmanın gerçekleşmeye başladığ 1980'lerden bu yana çok değişmiştir.

Türkiye'ye ilişkin ihracat denklemlerinde dikkati çeken husus, 1980'leri ve 1990'ları inceleyen çalışmaların reel kurun değer kaybının ve ihracat teşviklerinin ihracatı artırıcı etkilerini vurguluyor olmasıdır (Aslan ve Wijnbergen (1993), Şahinbeyoğlu ve Ulaşan (1999), Vergil (2002), Achy ve Sekkat (2003), Utkulu ve Seymen (2004)). Diğer taraftan, 2000'li yılları analiz eden çalışmaların çoğu reel kurun ihracat üzerinde anlamlı bir etkisinin bulunmadığı sonucuna ulaşmaktadır (Aydın vd. (2004), Yılmaz ve Kaya (2007), Koççat (2008), Uz (2010), Altıntaş vd. (2011)). Bazı çalışmalarda reel kur değerlendikçe ihracatın arttı̆̆ı bile gösterilmektedir (Coşar (2002), Sarıkaya (2004), Saygılı (2010)). Az sayıda yakın dönemi içeren çalışmada ise ihracat ile reel kur arasındaki negatif bağlantının devam ettiğine işaret edilmektedir ((Yalçınkaya (2009), Saatçioğlu ve Karaca (2010), Özkaya (2011)). Ancak bu çalışmalarda da reel kur değerlenmesinin ihracatı azaltıcı etkisinin genellikle çok küçük boyutlarda, çok zayıf bir etki olduğu görülmektedir.

$\mathrm{Bu}$ durum, son yıllarda reel kur ile ihracat arasındaki bağlantının büyük ölçüde koptuğunu göstermektedir. Son dönemde Türkiye'nin ihracatında gözlemlenen yapısal değişimin bunun en önemli sebeplerinden biri olduğu düşünülmektedir. Türkiye, diş ticarete yeni açılmakta olduğu 1980'li yıllarda ve 1990'lı yılların başında, büyük ölçüde fiyat rekabetine dayalı, katma değeri düşük, tekstil ve giyim gibi ürünlerin ağırlıklı ihracatçısı iken, zaman içinde ihracatın sektör yapısı önemli ölçüde değişerek katma değeri daha yüksek motorlu kara taşıtları, elektrikli ve elektriksiz makineler gibi ürünler ilk sıralara yerleşmiştir. Tekstil ve giyimde ise katma değeri daha yüksek moda ve marka ürünlere yönelinmiştir. Bu ürünlerde fiyat rekabetinden çok kalite, tasarım gibi unsurlar ön 
plana çıktığından, kur etkisi de azalmıştır. Esasen, 2002 y1lından 2010 yılına kadarki dönemde TL reel kuru değerlenirken ihracatımız istikrarlı bir şekilde yüksek artışlar göstermektedir. Bu durum daha regresyon analizi yapılmadan bile grafiklerde göze çarpmaktadır. Reel kurdaki artışlar, ihracatçılar bu artışları aynen dış fiyatlarına yansıtamadıkları sürece kar marjlarını düşürücü etki yapabilir; ancak, değerli kura rağmen artan ihracat, ihracatçılarımızın reel kurun değerlenmesinden kaynaklanan dezavantajları bir şekilde telafi edebildiklerini göstermektedir. İhracatçıların son dönemde artan oranda fuarlara ve ticaret heyetlerine katılımı, etkin pazarlama faaliyetleri, dâhilde işleme rejimi kapsamında üretimde kullanılan girdilerin gümrük vergileri olmadan ithal edilmesi imkânı bu tablonun ortaya çıkmasında etkili olmuş olabilir.

Türkiye'nin 1980'lerini ve 1990'larını inceleyen çalışmalarla 2000'lerini inceleyen çalışmalarda görülen bir başka farklılık ise ihracat teşviklerinin denklemlerden ihracatı etkileyen bağımsız değişkenlerden biri olmaktan çıkarılmasıdır. Türkiye'nin dış ticaretini liberalleştirmeye başladığı 1980'li yıllarda ihracatı artırmak için nakit teşvikler dâhil çok sayıda teşvik verilmekteydi. Ancak sonrasında Türkiye'nin 1995 yılında Dünya Ticaret Örgütüne (DTÖ) kurucu üye olması ve 1996 yılında AB ile Gümrük Birliği'ne (GB) girmesi sonucunda, uluslararası yükümlülükleri çerçevesinde nakit teşvikler başta olmak üzere uluslararası ticareti bozucu nitelikte sayılan teşvikleri kaldırmış, DTÖ ve GB'nce benimsenen teşvikler mevzuata dâhil edilmiştir. Bunun sonucunda teşvikler sayıca ve miktarca azalmış, ihracatçılar için önemli olmaya devam etmekle beraber, ihracatımızı etkileyen en önemli faktörlerden biri olmaktan çıkmıştır.

Diğer taraftan, dış talebin Türkiye'nin ihracatını her dönemde pozitif yönde etkileyen en önemli faktörlerden biri olduğu görülmektedir. Türkiye'nin ticaret ortaklarının milli gelirlerindeki artış söz konusu ülkelerin ithalatlarını artırarak ihracatımızı artırıcı yönde etki yapmaktadır. Türkiye'yi inceleyen hemen hemen tüm çalışmalar dış talebin önemini vurgulamaktadır (Şahinbeyoğlu ve Ulaşan (1999), Vergil (2002), Utkulu ve Seymen (2004), Coşar (2002), Aydın vd. (2004), Lehman vd. (2007), Akal (2008), Uz (2010), Vergil (2010), Saatçioğlu ve Karaca (2010), Altıntaş vd. (2011), Özkaya (2011), Atıc1 vd. (2011)).

Türkiye'nin ihracat arz denklemini kuran çalışmalar, Türkiye'nin ihracat arzını etkileyen en önemli değişkenlerden birinin iç talep/yerli üretim değişkeni olduğunu göstermektedir (Coşar (2002), Aydın vd. (2004), Sarıkaya (2004), Vergil (2010), Değer ve Genç (2010), Yurtkur ve Bayramoğlu (2012)). Genellikle Türkiye'nin GSYH'sı veya sanayi üretim endeksi ile ölçülen iç talep değişkeni ile ihracat arasında pozitif ilişki bulunmaktadır. Diğer önemli değişkenler birim iş gücü maliyetleri ve reel ücretlerdir. Beklendiği gibi, üretim maliyetlerindeki artış ihracat arzını düşürücü etkide bulunmaktadır (Sarıkaya (2004), Aydın vd. (2004), Saygılı (2010)). Tersine, verimlilik artışları ise maliyetleri düşürerek ihracat arzını artırıcı etkide bulunmaktadır (Saygılı (2010)). 
Aslan ve Wijnbergen (1993) ile Vural ve Zortuk (2011), Türkiye'nin ihracat arz ve talep denklemlerini eş anlı olarak tahmin etmişlerdir. Aslan ve Wijnbergen (1993) iki aşamalı en küçük kareler yöntemini kullandıkları modellerinde arz denkleminde göreli fiyatlar, kara borsa primi, ihracat teşvikleriyle ve talep denkleminde petrol ihracatçısı olan ve olmayan ülkelerin talebi ile ticaret ortaklarının GSYH'sı ve reel kuru bağımsız değişkenler olarak almışlardır. Vural ve Zortuk (2011) ise üç aşamalı en küçük kareler yöntemi ile tahmin ettikleri denklemlerinde arz modelinin bağımsız değişkenlerini ihracat fiyatlarının yerel fiyatlara oranı, bütçe açığı/GSYH, doğrudan yabancı yatırımlar, ihracatın gecikmeli değerleri ve yapısal kırılmaları ölçmek üzere kullanılan kukla değişkenler olarak belirlerken, talep denkleminde reel kur, dünya GSYH'sı, ihracatın bir dönem gecikmeli değerini bağımsız değişkenler olarak almışlardır.

Literatürdeki makalelere ilişkin detaylar Ek Tablo: 1'den görülebilir. Literatürde Türkiye'nin son dönemde sektörel ihracatını zaman serisi kullanarak inceleyen çalışmaya rastlanmamıştır. Sektörel analizlerin öneminden hareketle, bu çalışmanın amacı literatürdeki bu boşluğu doldurmaktır.

\section{Veriler ve Yöntem}

Bu çalışmanın amacı, Türkiye'nin son dönem verileri kullanılarak (1998Ç12012Ç1) imalat sanayi sektörlerinin ihracat denklemlerinin tahmin edilmesidir. ISIC Rev. 3 bazında Türkiye'nin en çok ihraç ettiği ilk dört imalat sanayi sektöründe, ihracatı belirleyen en önemli faktörler Vektör Hata Düzeltme (VEC) yöntemi ile tahmin edilmiştir. Her bir sektör için uzun dönemli eşbütünleşme ilişkisi Tamamen Değiştirilmiş En Küçük Kareler (Fully Modified OLS-FMOLS) yöntemi ile hesaplanmıştır (Phillips ve Hansen, 1990). 2001 ve 2009 krizleri sebebiyle bir değişim olup olmadığını görmek için sırasıyla, 2001Ç1-2001Ç4 ve 2008Ç3-2009Ç3 dönemlerini kapsayan kukla değişkenler de modele dâhil edilmiştir. Ayrıca mevsimsel faktörleri içermek üzere yılın her bir çeyreği için kukla değişkenler tanımlanmıştır.

Regresyonun bağımlı değişkeni, ISIC Rev. 3 bazında 2 basamaklı imalat sanayi sektörlerinin çeyrekler bazında ihracatıdır. İhracat verileri Türkiye İstatistik Kurumu'ndan (TÜIKK) alınmıştır. Sınıflama sistemi Ek Tablo: 2’de yer almaktadır.

Aşağıdaki tabloda 1998-2011 yılları arasında ISIC Rev. 3 sektörleri bazında Türkiye'nin ihracat rakamları yer almaktadır. 
Tablo: 1

ISIC Rev. 3 Sinıflamasına Göre İmalat Sanayi İhracatı (1998-2011 Yılları)

\begin{tabular}{|c|c|c|c|c|c|c|c|c|c|c|c|c|c|c|c|}
\hline iyon 5 : & Sektör Adı & 1998 & 1999 & 2000 & 2001 & 2002 & 2003 & 2004 & 2005 & 2006 & 2007 & 2008 & 2009 & 2010 & 2011 \\
\hline 27 & Ana Metal Sanayi & 2198 & 2064 & 2247 & 2921 & 3239 & 3884 & 6816 & 6888 & 9334 & 12349 & 22570 & 15103 & 14427 & 17062 \\
\hline 34 & Motorlu Kara Taşit ve Römorklar & 1049 & 1615 & 1745 & 2657 & 3603 & 5437 & 8813 & 10226 & 12677 & 17016 & 19362 & 12863 & 14857 & 17044 \\
\hline 17 & Tekstil Ürünleri & 4794 & 4558 & 4614 & 4943 & 5533 & 6841 & 7998 & 8743 & 9266 & 10805 & 11323 & 9559 & 10932 & 12920 \\
\hline 18 & Giyim Esyast & 5716 & 5270 & 5417 & 5398 & 6615 & 8154 & 9340 & 9925 & 10175 & 11795 & 11504 & 9603 & 10618 & 11633 \\
\hline 29 & Baska Yerde Sinfflandirlimamıs Makine ve Techhizat & 1107 & 1212 & 1376 & 1564 & 2078 & 3119 & 3913 & 4865 & 6006 & 8032 & 9763 & 8070 & 9059 & 11126 \\
\hline 15 & GIda Ürünleri ve içecek & 2357 & 2040 & 1836 & 2016 & 1881 & 2650 & 3349 & 4272 & 4339 & 5164 & 6476 & 5931 & 6703 & 8881 \\
\hline 24 & Kimyasal Madde ve Ürünler & 1277 & 1235 & 1397 & 1481 & 1581 & 1926 & 2556 & 2818 & 3481 & 4057 & 4995 & 4300 & 5706 & 6743 \\
\hline 25 & Plastik ve Kauçuk Ürünleri & 685 & 668 & 781 & 941 & 1085 & 1464 & 1959 & 2486 & 3016 & 3930 & 4750 & 4035 & 4887 & 6241 \\
\hline 28 & Metal Esya Sanayi (Makine ve Teçhizatı Hariç) & 664 & 648 & 661 & 733 & 932 & 1503 & 2200 & 2685 & 3350 & 4251 & 5531 & 4470 & 4973 & 6230 \\
\hline 23 & Kok Kömürü, Rafine Edilmiş Petrol Ürünleri ve Nükleer Yakttlar & 241 & 315 & 301 & 416 & 670 & 954 & 1364 & 2519 & 3402 & 4922 & 7325 & 3650 & 4153 & 6122 \\
\hline 31 & Baska Yerde SinfflandirnImamıs Elektrikli Mekina ve Cihazlar & 756 & 692 & 825 & 1038 & 1057 & 1221 & 1576 & 1933 & 2822 & 4106 & 4975 & 4099 & 4864 & 5863 \\
\hline 26 & Metalik Olmayan Diğer Mineral Ürünler & 945 & 957 & 1121 & 1231 & 1468 & 1800 & 2317 & 2687 & 2799 & 3398 & 4321 & 3769 & 3989 & 4042 \\
\hline 36 & Mobilya ve Baskka Yerde Sinfflandinlmamıs Diğer Ürünler & 379 & 487 & 631 & 719 & 945 & 1315 & 1771 & 2238 & 2356 & 3101 & 3500 & 2786 & 3283 & 4014 \\
\hline 32 & Radyo, Televizyon, Haberlessme Teçhizat ve Cihazlart & 862 & 771 & 962 & 1002 & 1575 & 1948 & 2883 & 3150 & 3088 & 2766 & 2277 & 1919 & 1951 & 2111 \\
\hline 35 & Diğer Ulaşım Araçlan & 315 & 771 & 882 & 948 & 529 & 1037 & 1349 & 1707 & 2140 & 2747 & 3360 & 2418 & 1659 & 199 \\
\hline 21 & Kağ̈t ve Kağ̈t Ürünleri & 150 & 149 & 164 & 242 & 303 & 367 & 457 & 559 & 601 & 836 & 1052 & 982 & 1194 & 1407 \\
\hline 19 & I çantast, Saraciye ve Ayakkabt & 271 & 181 & 190 & 212 & 214 & 286 & 328 & 370 & 436 & 559 & 607 & 499 & 656 & 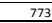 \\
\hline & Ağaç ve $M \circ$ & & & & & & & & & & & & & & \\
\hline $\begin{array}{r}20 \\
33 \\
\end{array}$ & \begin{tabular}{|l} 
Yapilan Maddeler \\
Tibbi Alettler; Hassa
\end{tabular} & \begin{tabular}{l|}
71 \\
75
\end{tabular} & 68 & \begin{tabular}{l|}
63 \\
75
\end{tabular} & $\begin{array}{r}109 \\
77\end{array}$ & $\begin{array}{r}r 18 \\
89\end{array}$ & $\begin{array}{l}146 \\
129\end{array}$ & \begin{tabular}{l|}
204 \\
173
\end{tabular} & \begin{tabular}{ll|}
250 & \\
198
\end{tabular} & $\begin{array}{l}336 \\
244\end{array}$ & $\begin{array}{l}455 \\
337\end{array}$ & $\begin{array}{l}535 \\
404\end{array}$ & $\begin{array}{l}510 \\
367\end{array}$ & \begin{tabular}{|l|l|}
472 \\
412
\end{tabular} & $\frac{653}{499}$ \\
\hline 16 & Tütün Ürünleri & 68 & 83 & 123 & 81 & 100 & 90 & 78 & 122 & 182 & 195 & 277 & 266 & 296 & 301 \\
\hline 22 & Basim ve Yayım; Plak, Kaset Vb. & 41 & 48 & 43 & 43 & 49 & 67 & 82 & 105 & 108 & 130 & 145 & 148 & 141 & 164 \\
\hline 30 & Büro, Muhasebe ve Bilgi is śleme Makinaları & 43 & 60 & 63 & 52 & 40 & 41 & 52 & 70 & 89 & 130 & 135 & 100 & 134 & 140 \\
\hline & Toplam ihracat & 26974 & 26587 & 27775 & 31334 & 36059 & 47253 & 63167 & 73476 & 85535 & 107272 & 132027 & 102143 & 113883 & 134 \\
\hline
\end{tabular}

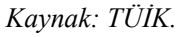

2011 yılı itibariyle en çok ihracatı yapılan sektör, 17 milyar dolar ile ana metal sanayidir. Bu sektörü yine 17 milyar dolar ihracatıyla motorlu kara taşıtları ve römorklar izlemektedir. Tekstil ürünleri ve giyim eşyaları sektörleri sırasıyla 12,9 ve 11,6 milyar dolar ihracatlarıyla 3. ve 4. sırayı paylaşmaktadır.

Tablo: 2

ISIC Rev. 3 Sınıflamasına Göre İmalat Sanayi İhracatının Toplam İçindeki Payı (1998-2011 Yılları)

\begin{tabular}{|c|c|c|c|c|c|c|c|c|c|c|c|c|c|c|c|}
\hline \% Pay & Sektör Adı & 1998 & 1999 & 2000 & 2001 & 2002 & 2003 & 2004 & 2005 & 2006 & 2007 & 2008 & 2009 & 2010 & 2011 \\
\hline 27 & Ana Metal Sanayi & 8.15 & 7.76 & 8.09 & 9.32 & 8.98 & 8.22 & 10.79 & 9.37 & 10.91 & 11.51 & 17.09 & 14.79 & 12.67 & 12.65 \\
\hline 34 & Motorlu Kara Taşitı ve Römorklar & 3.89 & 6.07 & 6.28 & 8.48 & 9.99 & 11.51 & 13.95 & 13.92 & 14.82 & 15.86 & 14.67 & 12.59 & 13.05 & 12.63 \\
\hline 17 & Tekstil Ürünleri & 17.77 & 17.14 & 16.61 & 15.78 & 15.34 & 14.48 & 12.66 & 11.90 & 10.83 & 10.07 & 8.58 & 9.36 & 9.60 & 9.58 \\
\hline 18 & Giyim Esyası & 21.19 & 19.82 & 19.50 & 17.23 & 18.35 & 17.26 & 14.79 & 13.51 & 11.90 & 11.00 & 8.71 & 9.40 & 9.32 & 8.62 \\
\hline 29 & Baska Yerde Sinfflandirlmamıs Makine ve Teçhizat & 4.11 & 4.56 & 4.95 & 4.99 & 5.76 & 6.60 & 6.20 & 6.62 & 7.02 & 7.49 & 7.39 & 7.90 & 7.96 & 8.25 \\
\hline 15 & Gida Ürünleri ve içecek & 8.74 & 7.67 & 6.61 & 6.43 & 5.22 & 5.61 & 5.30 & 5.81 & 5.07 & 4.81 & 4.90 & 5.81 & 5.89 & 6.58 \\
\hline 24 & Kimyasal Madde ve Ürünler & 4.74 & 4.64 & 5.03 & 4.72 & 4.38 & 4.08 & 4.05 & 3.84 & 4.07 & 3.78 & 3.78 & 4.21 & 5.01 & 5.00 \\
\hline 25 & Plastik ve Kauçuk Ürünleri & 2.54 & 2.51 & 2.81 & 3.00 & 3.01 & 3.10 & 3.10 & 3.38 & 3.53 & 3.66 & 3.60 & 3.95 & 4.29 & 4.63 \\
\hline 28 & Metal Eşya Sanayi (Makine ve Teçhizatı Hariç) & 2.46 & 2.44 & 2.38 & 2.34 & 2.59 & 3.18 & 3.48 & 3.65 & 3.92 & 3.96 & 4.19 & 4.38 & 4.37 & 4.62 \\
\hline 23 & $\begin{array}{l}\text { Kok Kömürü, Rafine Edilmiş Petrol Ürünleri ve Nükleer } \\
\text { Yakttlar }\end{array}$ & 0.89 & 1.19 & 1.08 & \begin{tabular}{|l|}
1.33 \\
\end{tabular} & 1.86 & 2.02 & 2.16 & 3.43 & 3.98 & 4.59 & 5.55 & 3.57 & 3.65 & 4.54 \\
\hline 31 & $\begin{array}{l}\text { Baska Yerde Sinfflandirılmamıs Elektrikli Makina ve } \\
\text { Cihazlar }\end{array}$ & 2.80 & 2.60 & 2.97 & 3.31 & 2.93 & 2.58 & \begin{tabular}{l|l}
2.49 \\
\end{tabular} & 2.63 & 3.30 & 3.83 & 3.77 & 4.01 & 4.27 & 4.35 \\
\hline 26 & Metalik Olmayan Diğer Mineral Ürünler & 3.50 & 3.60 & 4.04 & 3.93 & 4.07 & 3.81 & 3.67 & 3.66 & 3.27 & 3.17 & 3.27 & 3.69 & 3.50 & 3.00 \\
\hline 36 & $\begin{array}{l}\text { Mobilya ve Baska Yerde SıInfflandirrlmamıs Diğer } \\
\text { Ürünler }\end{array}$ & 1.40 & 1.83 & 2.27 & 2.29 & 2.62 & 2.78 & 2.80 & 3.05 & 2.75 & 2.89 & 2.65 & 2.73 & 2.88 & 2.98 \\
\hline 32 & Radyo, Televizyon, Haberleșme Teçhizatı ve Cihazları & 3.20 & 2.90 & 3.46 & 3.20 & 4.37 & 4.12 & 4.56 & 4.29 & 3.61 & 2.58 & 1.72 & 1.88 & 1.71 & 1.56 \\
\hline 35 & Diğer Ulașım Arạ̣ları & 1.17 & 2.90 & 3.18 & 3.03 & 1.47 & 2.20 & 2.14 & 2.32 & 2.50 & 2.56 & 2.55 & 2.37 & 1.46 & 1.48 \\
\hline 21 & Kağıt ve Kağıt Ürünleri & 0.56 & 0.56 & 0.59 & 0.77 & 0.84 & 0.78 & 0.72 & 0.76 & 0.70 & 0.78 & 0.80 & 0.96 & 1.05 & 1.04 \\
\hline 19 & $\begin{array}{l}\text { Dabaklanmıs Deri, Bavul, El çantası, Saraciye ve } \\
\text { Ayakkabı }\end{array}$ & 1.01 & 0.68 & 0.68 & 0.68 & 0.59 & 0.60 & 0.52 & 0.50 & 0.51 & 0.52 & 0.46 & 0.49 & 0.58 & 0.57 \\
\hline 20 & $\begin{array}{l}\text { Ağaç ve Mantar Ürünleri (Mobilya Hariç); Hasır Vb. } \\
\text { Örülerek Yapılan Maddeler }\end{array}$ & 0.26 & 0.26 & 0.23 & 0.35 & 0.33 & 0.31 & 0.32 & 0.34 & 0.39 & 0.42 & 0.41 & 0.50 & 0.50 & 0.48 \\
\hline 33 & Tibbi Aletler; Hassas Optik Aletler ve Saat & 0.28 & 0.25 & 0.27 & 0.25 & 0.25 & \begin{tabular}{l|}
0.27 \\
\end{tabular} & \begin{tabular}{l|}
0.27 \\
\end{tabular} & 0.27 & 0.29 & 0.31 & 0.31 & $\begin{array}{l}0.36 \\
\end{array}$ & 0.36 & 0.37 \\
\hline 16 & Tütün Ürünleri & 0.25 & 0.31 & 0.44 & 0.26 & 0.28 & 0.19 & $\begin{array}{ll}0.12 \\
\end{array}$ & 0.17 & 0.21 & 0.18 & 0.21 & 0.26 & 0.26 & 0.22 \\
\hline 22 & Basım ve Yayım; Plak, Kaset Vb. & 0.15 & 0.18 & 0.15 & 0.14 & 0.14 & 0.14 & 0.13 & 0.14 & 0.13 & 0.12 & 0.11 & 0.14 & 0.12 & 0.12 \\
\hline 30 & Büro, Muhasebe ve Bilgi ișleme Makinalar & 0.16 & 0.23 & 0.23 & 0.17 & 0.11 & 0.09 & 0.08 & 0.09 & 0.10 & 0.12 & 0.10 & 0.10 & 0.12 & 0.10 \\
\hline & Toplam ihracat & 100.00 & 100.00 & 100.00 & 100.00 & 100.00 & 100.00 & 100.00 & 100.00 & 100.00 & 100.00 & 100.00 & 100.00 & 100.00 & 100.00 \\
\hline
\end{tabular}

Kaynak: TÜIK.

Yukarıdaki tabloda, her bir imalat sanayi sektörünün Türkiye'nin toplam ihracatından aldığı pay gösterilmektedir. 1998-2011 yılları arasında tekstil ve giyim 
sektörlerinin ihracat paylarındaki yüksek oranlı düşüş ile ana metal sanayi, motorlu kara taşıtları, makine ve teçhizat, petrol ürünlerindeki yüksek oranlı ihracat payı artışları dikkati çekmektedir. Türkiye'nin ihracat yapısı katma değeri yüksek ürünlere doğru bir dönüşüm içindedir.

Bu çalışmada, 2011 yılı itibariyle Türkiye'nin en çok ihracat yaptığı ilk 4 sektör; 27-Ana Metal Sanayi, 34-Motorlu Kara Taşıtları ve Römorklar, 17-Tekstil Ürünleri, 18Giyim Eşyası incelenmiştir.

Regresyon analizinde kullanılmak üzere, bağımsız değişkenler olarak; incelenen sektörün ihracat birim fiyatları, sanayi üretim endeksi, kapasite kullanım oranı, reel kur, avro/dolar paritesi, ticaret ortaklarının GSYH'sı, birim iş gücü maliyetleri, sektörün kullandığ 1 çeşitli girdilerin maliyetleri (ana metal sanayi için enerji fiyatları, metal fiyat endeksi, motorlu kara taşıtları sektörü için kauçuk ve çelik fiyatları, tekstil sanayi için pamuk fiyatları) alınmıştır.

İhracat birim fiyatları ve sanayi üretim endeksi verileri TÜiK verileridir. TÜİK, sanayi üretim endeksi hesaplamalarında, 1997 bazlı endeksi ISIC Rev. 3 Bazında tutmakta ve seri 2008'e kadar gelmektedir. TÜIK' in 2005 bazlı serisi ise NACE Rev. 1.1 bazında tutulmuştur. Bu sebeple 1997 bazlı endeks temel alınmış, 2008 sonrası için ISIC Rev. 3'e karşılık gelen NACE Rev.1.1 sektörlerindeki sanayi üretim artış oranları uygulanarak seri 2012 başına kadar uzatılmıştır. İncelediğimiz dört sektörde ISIC Rev.3 önemli bir değişikliğe uğramadığından uzatma işleminin sapma yaratmayacağı düşünülmektedir. Reel kur endeksi Türkiye Cumhuriyet Merkez Bankası TÜFE bazlı seridir; seri hesaplanırken Türkiye'nin dış ticaretinin \%80'ini içeren 36 ülke ile ticaret ağırlıkları kullanılmıştır. Kapasite kullanım oranları 2009 yılı sonuna kadar ISIC Rev 3. bazında TÜIK'ten alınmıştır, 2010 yılından itibaren ise verileri Türkiye Cumhuriyet Merkez Bankası tutmaya başlamış olup, bu tarihten sonrası TCMB serilerinden alınmıştır. Avro/dolar paritesi Avrupa Merkez Bankasının internet sayfasından elde edilmiştir. Ticaret ortaklarının GSYH'sı her bir sektör için o sektörün en çok ihracat yaptığı ülkelerin reel GSYH endeksi alınarak ve o sektörün ihracatındaki payı ile ağırlıklandırılarak hesaplanmıştır. Birim işgücü maliyetleri ise aşağıdaki formüle göre hesaplanmıştır:

$$
\mathrm{ULC}=\mathrm{W} . \mathrm{L} / \mathrm{Q}
$$

Burada ULC birim iş gücü maliyetini, W ücret seviyesini, L çalışılan saati ve Q üretimi temsil etmektedir. Ücret seviyesi, çalışllan saat ve üretim değişkenlerini temsil etmek üzere, yine her sektör için, TÜiK verilerinden sırasıyla imalat sanayi ücret endeksi, imalat sanayi çalışılan saat endeksi ve imalat sanayi üretim endeksi alınarak birim iş gücü maliyeti hesaplanmıştır.

Değişkenlerin logaritmaları alınarak modele dâhil edildiğinden, regresyon tahmininden elde edilen katsayı tahminleri, esneklikleri (bağımsız değişkendeki yüzde bir değişime karşılık bağımlı değişkendeki yüzde değişimi) vermektedir. 
Her bir sektör için yapılan FMOLS regresyon denklemi değişkenler arasındaki uzun dönemli eşbütünleşme ilişkisini verecek şekilde aşağıdaki gibi ifade edilmiştir:

Arz yanlı bir faktör olarak sanayi üretim endeksinin (SANURETEND) ve kapasite kullanım oranının (KAPASITE) ihracatı pozitif yönde etkilemesi, üretim ve kapasite kullanım oranları arttıkça hem ihracatın, hem de iç satışların artması beklenmektedir. Ayrıca her bir sektör için, kendi sanayi üretimi ve kapasite kullanımının yanısıra, kullanıcısı ve tedarikçisi olduğu sektörlerin üretimi ve kapasite kullanımı değişkenleri de denenmiştir.

Literatürdeki çok sayıdaki çalışma Türkiye'nin ihracatında dış talebin en önemli faktörlerden biri olduğunu göstermektedir. Dolayısıyla o sektörün ticaret ortaklarının ağırlıklı GSYH'sının (GSYHTicOrtak) sektörel ihracatta pozitif ve anlamlı bir etkisinin olması beklenmektedir.

Reel kur (RKUR) artışının, özellikle ihracatçılar bu artışı, yoğun rekabet vs. sebeplerle dış piyasalarda fiyatlara yansıtamıyorlarsa ihracatçıların kar marjlarını düşürerek sektörel ihracatı olumsuz etkilemesi söz konusu olabilir. Ancak, özellikle Türkiye'nin ihracatı için son dönemi içeren çalışmalar TL'nin reel olarak değerlenmesinin ihracat üzerinde anlamlı bir etkisinin bulunmadığını göstermektedir.

İhracat birim fiyatları arttıkça, eğer talep aynı oranda veya daha yüksek oranda düşmezse, ihracat değer olarak daha yüksek bir meblağa karşıllk gelecektir; dolayısıyla ihracat birim fiyatlarının nominal ihracat üzerindeki etkisi pozitif anlamlı olacaktır. Birim iş gücü maliyetlerindeki artışın firma kârlarını düşürerek ihracatı azaltıcı yönde etkide bulunması beklenir.

Türkiye'nin ihracatının 2011 y1lı itibariyle \%47'nin avro, \%45'ini ise dolar cinsinden gerçekleştirildiği göz önünde bulundurulduğunda, avro/dolar paritesindeki değişmelerin ihracatımız üzerinde etkileri olacağı düşünülmektedir. Avro/dolar paritesinin artması avronun değerlenmesi, dolayısıyla en büyük ihracat pazarımız olan ve büyük ölçüde avro ile ihracat yaptığımız Avrupa ülkelerinin rekabet gücü kaybı anlamın geleceğinden ihracatta reel artış sağlayacaktır. Bunun yanı sıra, ihracatımız dolar olarak ölçüldüğünden, ihracat karşılığı kazanılan avronun dolar karşıllı̆ının artması sebebiyle nominal bir ihracat artışı da sağlanacaktır. Dolayısıyla parite değişkeninin katsayısının pozitif anlamlı olması beklenmektedir.

Zaman serisi denklemlerinde, regresyona giren bütün değişkenler aynı dereceden durağan değilse "sahte regresyon" (spurious regression) tehlikesi bulunmaktadır; dolayısıyla katsayılara güvenilemez. Bu sebeple denklemlerin tahmininden önce her bir değişkenin durağanlıkları test edilmiştir. Serilerin durağanlığını test etmek için Elliot, Rothenberg ve Stock (1996) tarafindan önerilen "ERS Point Optimal" testi kullanılmıştır. 
Birim kök testleri yapıldıktan sonra, tamamı birinci derecede bütünleşik, I(1), seriler arasındaki eş-bütünleşme ilişkisi FMOLS yöntemi ile tahmin edilmiştir. Sonrasında, bu denklem uzun dönemli denklem olarak alınmış, regresyon kalıntıları kullanılarak VEC modeli oluşturulmuştur.

FMOLS yöntemi, Phillips ve Hansen (1990) tarafından geliştirilmiştir. Phillips ve Hansen (1990), FMOLS yöntemi ile I(1) ve aralarında eşbütünleşme olan değişkenler arasında, içsel değişkenlerin olması durumunda da FMOLS tahmincisinin süper tutarlı, asimptotik olarak sapmasız ve asimptotik olarak normal dağıldığını ve bu tahminciden elde edilen $t$ istatistiklerinin asimptotik olarak normal dağıldığını dolayısıyla standard tabloların kullanılabileceği göstermişlerdir.

\section{Regresyon Sonuçları}

Bu bölümde, 2011 yılı itibariyle en çok ihracatı yapılan ilk 4 sektörün (Ana Metal, Motorlu Kara Taşıtları, Tekstil, Giyim) 1998Ç1-2012Ç1 dönemi arasında çeyrekler itibariyle, zaman serisi denklemleri kurularak değişkenler arasındaki uzun ve kısa dönemli ilişkiler tamamen değiştirilmiş en küçük kareler (Fully Modified Ordinary Least SquaresFMOLS) ve vektör hata düzeltme (Vector Error Correction-VEC) ile analiz edilmiştir.

\subsection{Birim Kök Testi Sonuçları}

Tüm değişkenlerin hangi düzeyde durağan olduklarını tespit etmek amacıyla, Elliot, Rothenberg ve Stock (1996) tarafindan önerilen ERS Point Optimal testi yapılmıştır. Birim kök testi sonucu elde edilen test sonuçları Ek Tablo-3'de sunulmaktadır. Tablodan görülebileceği üzere, ERS testine göre tüm değişkenlerin düzeyde birinci sıra fark durağandır (birinci dereceden bütünleşik, I(1)).

\subsection{Eş-Bütünleşme Testi Sonuçları}

Düzeyde durağan olmayan değişkenlerin uzun dönemde eşbütünleşik olup olmadıkları konusu uygulanacak yöntemin belirlenmesi açısından son derece önemlidir. Diğer taraftan bu çalışmada, sektörel olarak uzun dönemli etkiler Tamamen Değiştirilmiş En Küçük Kareler (FMOLS) yöntemi ile belirlenecek iken kısa dönemli etkilerin ortaya konulabilmesi amacıyla Hata Düzeltme Modelleri (VEC) kurulacaktır. VEC modelinin kurulabilmesi için de her bir sektörün ihracatını belirleyen ve birinci sıra fark durağan olan değişkenlerin eş bütünleşik olması gerekmektedir.

Her bir sektörün ihracatını belirleyen ve birinci sıra fark durağan (I(1)) olan değişkenlerin eş bütünleşik olup olmadıklarını test etmek amacıyla Johansen (1991, 1995) testi kullanılmıştır. Her bir sektöre ilişkin test sonuçları aşağıda sunulmaktadır. 
Tablo: 3

17-Tekstil Ürünleri ve 18-Giyim Eşyası Sektörü için Johansen Eş-bütünleşme Testleri

17. Sektör

\begin{tabular}{|c|c|c|c|c|}
\hline \multicolumn{5}{|c|}{ Sınırlanmamış Eşbütünleşme Rank Testi (Trace-İz) } \\
\hline \multirow[t]{2}{*}{ Hipotez } & \multirow{2}{*}{ Özdeğer } & \multirow{2}{*}{ İz İstatistiği } & \multicolumn{2}{|l|}{0,05} \\
\hline & & & \multicolumn{2}{|c|}{ Kritik Değerler P Değeri } \\
\hline Yok* & 0,608673 & 124,6909 & 95,75366 & 0,0001 \\
\hline En Çok $1^{*}$ & 0,556898 & 77,78034 & 69,81889 & 0,0101 \\
\hline En Çok 2 & 0,389092 & 37,08256 & 47,85613 & 0,3436 \\
\hline En Çok 3 & 0,129285 & 12,44213 & 29,79707 & 0,9154 \\
\hline En Çok 4 & 0,101375 & 5,52013 & 15,49471 & 0,7514 \\
\hline En Çok 5 & 0,003507 & 0,175664 & 3,841466 & 0,6751 \\
\hline \multicolumn{5}{|c|}{ İz testi 2 eşbütünleşme varlığını göstermektedir ( 0.05 anlamlılıkta) } \\
\hline \multicolumn{5}{|c|}{ * hipotezin ( 0.05 önem düzeyinde) reddedilmesini gösterir } \\
\hline \multicolumn{5}{|c|}{ **MacKinnon-Haug-Michelis (1999) p-değerleri } \\
\hline \multicolumn{5}{|c|}{ Sınırlanmamış Eşbütünleşme Rank Testi (Maksimum Özdeğer) } \\
\hline \multirow[t]{2}{*}{ Hipotez } & \multirow{2}{*}{ Özdeğer } & \multirow{2}{*}{$\begin{array}{c}\text { Max. } \\
\text { Özdeğer }\end{array}$} & \multicolumn{2}{|l|}{0,05} \\
\hline & & & \multicolumn{2}{|c|}{ Kritik Değerler $\mathrm{P}$ Değeri } \\
\hline Yok* & 0,608673 & 46,91061 & 40,07757 & 0,0073 \\
\hline En Çok $1^{*}$ & 0,556898 & 40,69779 & 33,87687 & 0,0066 \\
\hline En Çok 2 & 0,389092 & 24,64043 & 27,58434 & 0,1139 \\
\hline En Çok 3 & 0,129285 & 6,922002 & 21,13162 & 0,9569 \\
\hline En Çok 4 & 0,101375 & 5,344466 & 14,2646 & 0,6979 \\
\hline En Çok 5 & 0,003507 & 0,175664 & 3,841466 & 0,6751 \\
\hline \multicolumn{5}{|c|}{ Maksimum-özdeğer testi 2 adet eşbütünleşme varlığını göstermektedir } \\
\hline \multicolumn{5}{|c|}{ * hipotezin ( 0.05 önem düzeyinde) reddedilmesini gösterir } \\
\hline **MacKinn & Haug-Miche & lis (1999) p-de & eğerleri & \\
\hline
\end{tabular}

18. Sektör

\begin{tabular}{|c|c|c|c|c|}
\hline \multicolumn{5}{|c|}{ Sınırlanmamış Eşbütünleşme Rank Testi (Trace-Iz) } \\
\hline Hipotez & \multirow{2}{*}{ Özdeğer } & \multirow{2}{*}{ İz İstatistiği } & \multicolumn{2}{|l|}{0,05} \\
\hline & & & Kritik Değer & P değeri.** \\
\hline Yok* & 0,9261529 & 164,3414548 & 47,85612716 & $8,54 \mathrm{E}-11$ \\
\hline En Çok 1 & 0,196697912 & 23,63049378 & 29,79707334 & $2,17 E-01$ \\
\hline En Çok 2 & 0,166567742 & 11,80317418 & 15,49471288 & $1,67 \mathrm{E}-01$ \\
\hline En Çok 3 & 0,035720844 & 1,964220069 & 3,841465501 & $1,61 \mathrm{E}-01$ \\
\hline \multicolumn{5}{|c|}{ İz testi 1 eşbütünleşme varlığını göstermektedir ( 0.05 anlamlılıta) } \\
\hline \multicolumn{5}{|c|}{ * hipotezin ( 0.05 önem düzeyinde) reddedilmesini gösterir } \\
\hline \multicolumn{5}{|c|}{ **MacKinnon-Haug-Michelis (1999) p-değerleri } \\
\hline \multicolumn{5}{|c|}{ Sınırlanmamış Eşbütünleşme Rank Testi (Maksimum Özdeğer) } \\
\hline \multirow[t]{2}{*}{ Hipotez } & \multirow{2}{*}{ Özdeğer } & \multirow{2}{*}{$\begin{array}{c}\text { Max. } \\
\text { Özdeğer İst. }\end{array}$} & \multicolumn{2}{|l|}{0,05} \\
\hline & & & Kritik Değer & P Değeri.** \\
\hline Yok* & 0,9261529 & 140,7109611 & 27,58433779 & $8,6 \mathrm{E}-06$ \\
\hline En Çok 1 & 0,196697912 & 11,8273196 & 21,1316163 & $5,6 \mathrm{E}-01$ \\
\hline En Çok 2 & 0,166567742 & 9,838954111 & 14,26460015 & $2,2 \mathrm{E}-01$ \\
\hline En Çok 3 & 0,035720844 & 1,964220069 & 3,841465501 & $1,6 \mathrm{E}-01$ \\
\hline \multicolumn{5}{|c|}{ Maksimum-özdeğer testi 1 adet eşbütünleşme varlığını göstermektedir } \\
\hline \multicolumn{5}{|c|}{ * hipotezin (0.05 önem düzeyinde) reddedilmesini gösterir } \\
\hline \multicolumn{5}{|c|}{ **MacKinnon-Haug-Michelis (1999) p-değerleri } \\
\hline
\end{tabular}

Johansen eş-bütünleşme testi sonuçlarına göre, 17- Tekstil Ürünleri ihracatı için İz ve Maksimum Özdeğer istatistiklerine göre, değişkenler arasında iki eşbütünleşme ilişkisi bulunmuştur. Diğer taraftan, 18- Giyim Eşyası ihracatı için İz ve Maksimum Özdeğer istatistiklerine göre, değişkenler arasında bir eşbütünleşme ilişkisi bulunmuştur. 
Tablo: 4

27-Ana Metal Sanayi ve 34-Motorlu Kara Taşıtları Sektörü için Johansen Eşbütünleşme Testleri

27. Sektör

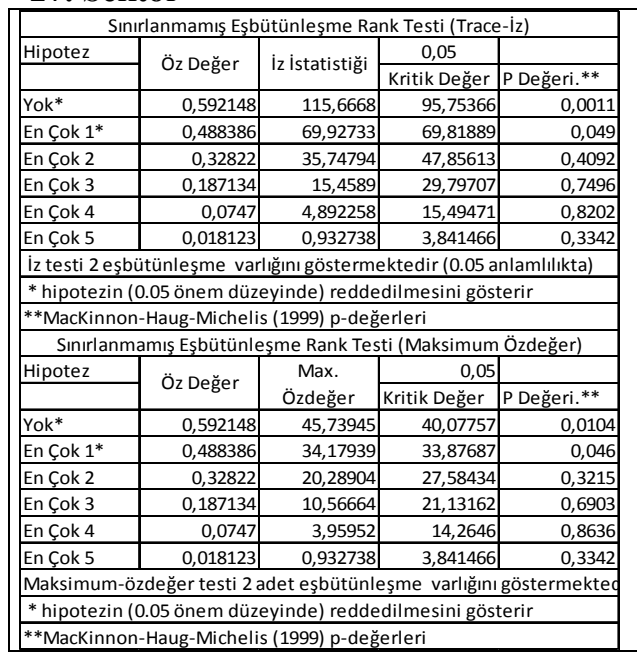

34. Sektör

\begin{tabular}{|c|c|c|c|c|}
\hline \multicolumn{5}{|c|}{ Sınırlanmamış Eşbütünleşme Rank Testi (Trace-i̇z) } \\
\hline \multirow{2}{*}{ Hipotez } & \multirow{2}{*}{ Öz Değer } & \multirow{2}{*}{ İz İstatistiği } & \multicolumn{2}{|l|}{0,05} \\
\hline & & & Kritik Değer & P Değeri** \\
\hline Yok* & 0,596549 & 100,44 & 88,8038 & 0,0056 \\
\hline En Çok 1 & 0,361597 & 51,42421 & 63,8761 & 0,3527 \\
\hline En Çok 2 & 0,219173 & 27,18978 & 42,91525 & 0,6701 \\
\hline En Çok 3 & 0,183056 & 13,83006 & 25,87211 & 0,6716 \\
\hline En Çok 4 & 0,052499 & 2,912098 & 12,51798 & 0,8868 \\
\hline \multicolumn{5}{|c|}{ İz testi 1 eşbütünleşme varlığını göstermektedir ( 0.05 anlamlılıkta) } \\
\hline \multicolumn{5}{|c|}{ * hipotezin ( 0.05 önem düzeyinde) reddedilmesini gösterir } \\
\hline \multicolumn{5}{|c|}{ **MacKinnon-Haug-Michelis (1999) p-değerleri } \\
\hline \multicolumn{5}{|c|}{ Sınırlanmamış Eşbütünleşme Rank Testi (Maksimum Özdeğer) } \\
\hline \multirow{2}{*}{ Hipotez } & \multirow{2}{*}{ Öz Değer } & \multirow{2}{*}{$\begin{array}{c}\text { Max- } \\
\text { Özdeğer } \\
\text { U̇statistiğj }\end{array}$} & 0,05 & \\
\hline & & & Kritik Değer & P Değeri.** \\
\hline Yok* & 0,596549 & 49,01575 & 38,33101 & 0,0021 \\
\hline En Çok 1 & 0,361597 & 24,23443 & 32,11832 & 0,3333 \\
\hline En Çok 2 & 0,219173 & 13,35971 & 25,82321 & 0,7755 \\
\hline En Çok 3 & 0,183056 & 10,91796 & 19,38704 & 0,5218 \\
\hline En Çok 4 & 0,052499 & 2,912098 & 12,51798 & 0,8868 \\
\hline \multicolumn{5}{|c|}{ Maksimum-özdeğer testi 1 adet eşbütünleşme varlığını göstermekte } \\
\hline \multicolumn{5}{|c|}{ * hipotezin ( 0.05 önem düzeyinde) reddedilmesini gösterir } \\
\hline \multicolumn{5}{|c|}{ **MacKinnon-Haug-Michelis (1999) p-değerleri } \\
\hline
\end{tabular}

Johansen eş-bütünleşme testi sonuçlarına göre, 27- Ana Metal Sanayi ihracatı için İz ve Maksimum Özdeğer istatistiklerine göre, değişkenler arasında iki eşbütünleşme ilişkisi bulunmuştur. Diğer taraftan, 34-Motorlu Kara Taşıtları ihracatı için İz ve Maksimum Özdeğer istatistiklerine göre, değişkenler arasında bir eşbütünleşme ilişkisi bulunmuştur.

\subsection{Tamamen Değiştirilmiş EKK Yöntemi (FMOLS) Sonuçları (Uzun Dönemli İlişkiler)}

Tüm sektörlerin ihracatını belirleyen değişkenlerin aralarında eş bütünleşme ilişkisi bulunduktan sonra, uzun dönemli ilişkileri incelemek için Tamamen Değiştirilmiş En Küçük Kareler Yöntemi (FMOLS) kullanılarak sektörler için uzun dönemli ilişkiler incelenmiştir. Aşağıda yer alan tablolarda her bir sektöre ilişkin regresyon sonuçları yer almaktadır. 
Tablo: 5

27-Ana Metal Ürünlerine İlişkin Regresyon Sonuçları

\begin{tabular}{|l|c|c|c|c|c|c|}
\hline Bağımsız Değişkenler & $\begin{array}{c}\text { GDP Tic. } \\
\text { Ortak }\end{array}$ & $\begin{array}{c}\text { ihracat } \\
\text { Birim } \\
\text { Değeri }\end{array}$ & $\begin{array}{c}\text { Sanayi } \\
\text { Üretimi } \\
(\mathbf{3 4})\end{array}$ & $\begin{array}{c}\text { Q2 Mevs. } \\
\text { Kuklası }\end{array}$ & $\begin{array}{c}\text { Q3 Mevs. } \\
\text { Kuklası }\end{array}$ & Sabit \\
\hline 27- Ana Metal ihracatı & 3,13 & 1,79 & $-0,54$ & 0,19 & $-0,12$ & 0,00 \\
$(0,00)$ & $(0,00)$ & $(0,00)$ & $(0,00)$ & $(0,00)$ & $(0,99)$ \\
\hline t Değeri & 8,93 & 14,33 & $-5,89$ & 4,21 & $-2,74$ & 0,00 \\
\hline Std. Hata & 0,35 & 0,12 & 0,09 & 0,04 & 0,04 & 0,09 \\
\hline R squared & \multicolumn{7}{|c|}{0,95} \\
\hline Düzeltilmiş R Squared & \multicolumn{7}{|c|}{0,95} \\
\hline
\end{tabular}

* Parantez içerisindeki değerler ilgili değisskene ilişkin p değerini vermektedir.

Tablo: 5'de “27-Ana Metal Sektörü” ihracatını belirleyen değişkenlere ilişsin esneklik katsayıları yer almaktadır. Tablo: 7'den görülebileceği üzere, söz konusu sektörün ihracatını etkileyen önemli değişkenler; Ticaret Ortaklarının GSYH'sı, Sektörel İhracat Birim Değer endeksi ve kullanıcı sektör konumundaki motorlu kara taşıtları sektörünün Sanayi Üretimi olarak bulunmuştur.

Esneklik katsayıları değerlendirildiğinde, en önemli değișkenin Ticaret Ortaklarının GSYH'sı olduğu görülmektedir. Ticaret Ortaklarının GSYH'sı ortalama \%1 artış gösterdiğinde söz konusu sektörün ihracatı ortalama \%3,13 artış göstermektedir. Diğer taraftan İhracat Birim Fiyatları bir diğer önemli değişken olup, İhracat Fiyatlarında meydana gelecek \%1 artış sektör ihracatını ortalama \%1,79 artırmaktadır. Bir başka deyişle, fiyat artışlarına karşı, sektörün ürünlerine olan talep aynı oranda azalmamaktadır. Regresyon sonuçlarına göre, kullanıcı sektör motorlu kara taşıtları sektörünün sanayi üretiminde meydana gelen artışlar sektörün ihracatını negatif yönlü etkilemektedir. $\mathrm{Bu}$ durum, motorlu kara taşıtları sanayi üretiminde meydana gelen artışla ana metal sanayi'nin iç piyasaya yoğunlaştığ 1 şeklinde yorumlanabilir. 
Tablo: 6

34-Motorlu Kara Taşıtları Sektörüne İlişkin Regresyon Sonuçları

\begin{tabular}{|c|c|c|c|c|c|c|c|}
\hline \begin{tabular}{|l|l|} 
Bağımsız Değişkenler \\
Bağımlı Değişken
\end{tabular} & $\begin{array}{c}\text { GDP Tic, } \\
\text { Ortak }\end{array}$ & $\begin{array}{l}\text { İhracat } \\
\text { Birim } \\
\text { Değeri }\end{array}$ & $\begin{array}{c}\text { Birim } \\
\text { İsgücü } \\
\text { Maliyeti }\end{array}$ & $\begin{array}{c}\text { Celik } \\
\text { Fiyatları }\end{array}$ & Trend & $\begin{array}{c}\text { Q1 Mevs, } \\
\text { Kuklası }\end{array}$ & $\begin{array}{c}\text { Q2 Mevs, } \\
\text { Kuklası }\end{array}$ \\
\hline 34- Motorlu Kara Taşıtları İhracatı & $\begin{array}{c}5,60 \\
(0,00)\end{array}$ & $\begin{array}{c}0,85 \\
(0,00)\end{array}$ & $\begin{array}{r}-1,08 \\
(0,00)\end{array}$ & $\begin{array}{l}-0,004 \\
(0,00)\end{array}$ & $\begin{array}{c}0,03 \\
(0,00)\end{array}$ & $\begin{array}{c}0,08 \\
(0,03)\end{array}$ & $\begin{array}{c}0,09 \\
(0,02)\end{array}$ \\
\hline t Değeri & 7,33 & 3,79 & $-5,19$ & $-4,46$ & 5,96 & 2,22 & 2,33 \\
\hline Std, Hata & 0,76 & 0,22 & 0,21 & 0,001 & 0,004 & 0,03 & 0,03 \\
\hline R squared & \multicolumn{7}{|c|}{0,96} \\
\hline Düzeltilmiş R Squared & \multicolumn{7}{|c|}{0,96} \\
\hline
\end{tabular}

* Parantez içerisindeki değerler ilgili değişkene ilişkin p değerini vermektedir.

Tablo: 6’da “34-Motorlu Kara Taşıtları” sektörü ihracatını belirleyen değişkenlere ilişkin esneklik katsayıları sunulmaktadır. Söz konusu sektörün ihracatını etkileyen önemli değişkenler; Ticaret Ortaklarının GSYH'sı, Sektörel İhracat Birim Değer endeksi, Çelik Fiyatları ve Birim İşgücü Maliyeti olarak bulunmuştur.

Esneklik katsayıları değerlendirildiğinde, en önemli değişkenin Ticaret Ortaklarının GSYH'sı olduğu görülmektedir. Ticaret Ortaklarının GSYH'sı ortalama \%1 artış gösterdiğinde söz konusu sektörün ihracatının ortalama \%5,6 artış göstermesi beklenmektedir. Diğer taraftan İhracat Birim Fiyatları bir diğer önemli değişken olup, İhracat Fiyatlarında meydana gelecek ortalama $\% 1$ artış sektör ihracatını \%0,85 artırmaktadır. Regresyon sonuçlarına göre, Birim İşgücü Maliyetlerinde meydana gelen artışın, uzun dönemde sektörün ihracatını azaltıcı yönde etki ettiği gözlemlenmektedir. Çelik fiyatlarındaki artış, katsayısı çok düşük olmakla beraber, ihracatı azaltıcı faktörlerden biridir.

Tablo: 7

17-Tekstil Ürünleri İhracatına İlişkin Regresyon Sonuçları

\begin{tabular}{|l|c|c|c|c|c|c|}
\hline Bağımsız Değişkenler & $\begin{array}{c}\text { GDP Tic. } \\
\text { Ortak }\end{array}$ & $\begin{array}{c}\text { Kapasite } \\
\text { Kullanımı }\end{array}$ & Parite & Reel Kur & $\begin{array}{c}\text { ihracat- } \\
\text { Giyim } \\
\text { Eşyası }\end{array}$ & Sabit \\
\hline 17- Tekstil Ürünleri İhracatı & $\begin{array}{c}3,83 \\
(0,00)\end{array}$ & $\begin{array}{c}2,90 \\
(0,00)\end{array}$ & $\begin{array}{c}1,99 \\
(0,00)\end{array}$ & $\begin{array}{c}-0,63 \\
(0,01)\end{array}$ & $\begin{array}{r}-0,99 \\
(0,00)\end{array}$ & $\begin{array}{c}14,3 \\
(0,00)\end{array}$ \\
\hline t Değeri & 7,12 & 7,22 & 7,83 & $-2,58$ & $-5,26$ & 5,07 \\
\hline Std. Hata & 0,53 & 0,4 & 0,25 & 0,24 & 0,18 & 2,81 \\
\hline R squared & \multicolumn{7}{|c|}{0,91} \\
\hline Düzeltilmiş R Squared & \multicolumn{7}{|c|}{0} \\
\hline
\end{tabular}

* Parantez içerisindeki değerler ilgili değişkene ilişkin p değerini vermektedir. 
Tablo: 7'de “17-Tekstil Ürünleri” ihracatını belirleyen değişkenlere ilişkin esneklik katsayıları sunulmaktadır. Ticaret Ortaklarının GSYH'sı, Kapasite Kullanımı, Parite, Reel Kur değişkenleri ile Tekstil Sektörünün kullanıcısı pozisyonunda olan giyim sektörü ihracatı değişkenleri istatistiksel olarak anlamlı bulunmuştur.

Esneklik katsayıları incelendiğinde, Ticaret Ortaklarının GSYH'sının Tekstil Ürünleri ihracatında da temel belirleyici olduğu görülmektedir. Diğer taraftan, Parite ve Kapasite Kullanım Oranlarında meydana gelen artışların sektörün ihracatını olumlu etkilediği görülmektedir. Kullanıcı sektör pozisyonunda bulunan Giyim Eşyası sektörü ihracatı ile Tekstil Ürünleri ihracatı arasında negatif yönlü bir ilişki vardır. Giyim Eşyası sektörünün ihracatının artması, bu sektöre hammadde tedariğini sağlayan Tekstil Sektörü'nün yurt içine yönelmesiyle ihracatının azalmasına sebep olmaktadır. Reel kur değerlenmesi de sektörün ihracatını azaltıcı etki yapmaktadır. Reel kurda yaşanacak $\% 1$ 'lik değerlenme tekstil ihracatında \%0,63 azalmaya sebep olmaktadır.

Tablo: 8

18-Giyim Eşyası Sektörüne İlişkin Regresyon Sonuçları

\begin{tabular}{|c|c|c|c|c|c|c|c|}
\hline $\begin{array}{l}\text { Bağımsız Değişkenler } \\
\text { Bağımlı Değişken }\end{array}$ & $\begin{array}{l}\text { GDP Tic. } \\
\text { Ortak }\end{array}$ & \begin{tabular}{|l} 
İhracat- \\
Tekstil \\
Ürünleri
\end{tabular} & $\begin{array}{l}\text { Ihracat } \\
\text { Birim } \\
\text { Değeri }\end{array}$ & $\begin{array}{c}\text { Birim } \\
\text { İsgücü } \\
\text { Maliyeti }\end{array}$ & Sabit & $\begin{array}{l}\text { Q3 Mevs. } \\
\text { Kuklası }\end{array}$ & $\begin{array}{c}\text { Kriz } 2009 \\
\text { Kuklası }\end{array}$ \\
\hline 18- Giyim Eşyası İhracatı & $\begin{array}{c}2,90 \\
(0,00)\end{array}$ & $\begin{array}{r}-0,37 \\
(0,00)\end{array}$ & $\begin{array}{c}1,45 \\
(0,00)\end{array}$ & $\begin{array}{r}-0,21 \\
(0,01)\end{array}$ & $\begin{array}{c}9,77 \\
(0,00)\end{array}$ & $\begin{array}{c}0,07 \\
(0,00)\end{array}$ & $\begin{array}{c}-0,06 \\
(0,074)\end{array}$ \\
\hline t Değeri & 9,03 & $-5,49$ & 12,53 & $-2,65$ & 12,96 & 3,23 & $-1,79$ \\
\hline Std. Hata & 0,32 & 0,06 & 0,11 & 0,07 & 0,75 & 0,02 & 0,03 \\
\hline R squared & \multicolumn{7}{|c|}{0,95} \\
\hline Düzeltilmiş R Squared & \multicolumn{7}{|c|}{0,94} \\
\hline
\end{tabular}

*Parantez içerisindeki değerler ilgili değişsene ilişkin p değerini vermektedir.

Tablo: 8'de “18-Giyim Eşyası” ihracatını belirleyen değişkenlere ilişkin esneklik katsayıları sunulmaktadır. Giyim eşyası sektörünün ihracatını etkileyen önemli değişkenler; ticaret ortaklarının GSYH'sı, sektörün hammadde tedarikçisi konumundaki tekstil ürünleri sektörü ihracatı, sektörel ihracat birim değer endeksi, birim işgücü maliyeti olarak bulunmuştur.

Esneklik katsayıları değerlendirildiğinde, en önemli değişkenin ticaret ortaklarının GSYH'sı olduğu görülmektedir. Ticaret ortaklarının GSYH'sı ortalama \%1 artış gösterdiğinde söz konusu sektörün ihracatının ortalama \%2,9 artış göstermesi beklenmektedir. İhracat birim fiyatları bir diğer önemli değişken olup, İhracat fiyatlarında meydana gelecek ortalama \%1 artış sektör ihracatını \%1,45 artırmaktadır. Birim İşgücü Maliyetleri’nin yükselmesi ise giyim eşyası sektörünün ihracatını azaltıcı yönde etkide bulunmaktadır. 2009 krizinin de sektör ihracatını olumsuz etkilediği görülmektedir. 
Dört sektöre ait denklem sonuçlarını karşılaştıracak olursak, tüm denklemlerde $\mathrm{R}^{2}$ 'nin \%90'ın üzerinde olduğunu, yani denklemlerin açıklama gücünün yüksek olduğunu görüyoruz. İncelenen sektörler itibariyle, sektörlerin ihracatını en fazla etkileyen değişkenin ticaret ortaklarının GSYH'sı olduğu söylenebilir. Esneklik katsayıları oldukça yüksektir, 2,9 ila 5,6 arasında değer almaktadır. Ticaret ortaklarının GSYH'sındaki artışa en duyarlı sektör 5,6 esnekliği ile motorlu kara taşıtlarıdır; bu sektördeki ticaret ortaklarımızın ağırlıklı GSYH'sındaki \%1'lik artış sektörün ihracatını \%5,6 oranında artırmaktadır. Tekstil sektörü 3,8 ve ana metal sektörü ihracatı 3,1 dış talep esnekliği ile onu takip etmektedir. İncelenen sektörler içinde en düşük esneklik 2,9 ile giyim eşyasındadır ki, o da oldukça yüksek bir esnekliğin varlığına işaret etmektedir.

Kapasite kullanım oranı, reel kur ve parite değişkenleri sadece tekstil ürünleri sektörü için istatistiksel olarak anlamlı bulunmuştur. Kapasite kullanım oranında meydana gelen $\% 1$ artış, söz konusu sektörün ortalama ihracatını \%2,9 artırmaktadır. Tekstil ihracatının avro-dolar parite esnekliği yaklaşık \%2'dir. Avro/dolar paritesindeki artış da sektörün en önemli pazarı olan $\mathrm{AB}$ ülkelerinin ithalatını artırarak, sektör ihracatını artırıcı etkide bulunmaktadır. Diğer taraftan reel kur'da meydana gelen ortalama \%1 artış, söz konusu sektörün ortalama ihracatını \%0,63 azaltmaktadır.

Reel kurun tekstil sektörü dışında anlamlı çıkmaması son dönem literatürdeki bulgularla uyumludur. Katma değeri yüksek sektörler genellikle reel kur değerlenmesinden olumsuz yönde etkilenmemekte, fiyat rekabetinin daha önemli olduğu tekstil sektörü olumsuz etkilenmektedir.

İhracat birim değer endeksi, giyim eşyası, ana metal ve motorlu taşıtlar sektörleri için istatistiksel olarak anlamlı olup, söz konusu sektörlerin ihracatını pozitif yönde etkilemektedir. İhracat birim değer endeksine ilişkin esneklikler; giyim eşyası sektörü için 1,45; ana metal sektörü için 1,8; motorlu taşıtlar sektörleri için 0,85 bulunmuştur. Bir başka deyişle, söz konusu sektörlerde fiyatlardaki yukarı yönlü hareketlerden diş talep olumsuz etkilenmemektedir.

Birim işgücü maliyeti; giyim eşyası, motorlu taşıtlar sektörleri için anlamlı olup esneklik katsayıları negatif bulunmuştur. Birim işgücü maliyetlerinde meydana gelen artışlar, söz konusu sektörlerde maliyetleri artırarak ihracatı azaltmaktadır. Esneklik katsayıları giyim için $-0,21$ ve motorlu kara taşıtları için $-1,08$ bulunmuştur.

Diğer taraftan incelenen sektörlerin ihracatlarında mevsimsellik bulunabileceğinden hareketle, denklemlere bazı mevsimsellik kuklaları eklenmiştir. İstatistiksel olarak anlamlı bulunan kukla değişkenlere denklemlerde yer verilmiştir. Ayrıca 2001 ve 2009 yıllarında yaşanan küresel krize ilişkin olarak denklemlere söz konusu krizlerin etkisini arındırabilmek amacıyla kriz kuklası eklenmiştir. Söz konusu kriz kuklalarından sadece 2009 krizi için olanı giyim eşyası sektöründe istatistiksel olarak anlamlı bulunmuştur. $\mathrm{Bu}$ durum sadece giyim sektörünün krizden olumsuz etkilendiği 
şeklinde değil, diğer değişkenlerin etkileri sabit tutulduğunda salt krizden kaynaklanan doğrudan bir etkinin giyim dışındaki sektörlerde görülemediği şeklinde yorumlanabilir. Bir başka deyişle, tüm sektörler krizin ticaret ortaklarının GSYH'sını düşürmesi vs. aracılığıyla dolaylı etkilerine maruz kalmışlardır ama sadece giyim sektörü krizden doğrudan da olumsuz olarak etkilenmiştir.

\subsection{Vektör Hata Düzeltme Modeli Sonuçları (Kısa Dönemli İlişskiler)}

Tamamen Değiştirilmiş En Küçük Kareler yöntemi ile uzun dönemli ilişkiler ortaya konulduktan sonra, Vektör Hata Düzeltme Modeli yardımıyla incelenen sektörler için kısa dönemli ilişkiler incelenmiştir. Vektör Hata Düzeltme Modeli (VEC) kurulmadan önce, değişkenlere zayıf dışsallık testi yapılmıştır (Johansen, 1995). Zayıf dışsallık testi sonuçlarına göre; teksil ürünleri ihracatı denkleminde, tekstil ürünleri sektörü ihracatı dışında, giyim eşyası sektörü sanayi üretimi de içsel değişken olarak tespit edilmiştir. Söz konusu denkleme ilişkin diğer değişkenler dışsal bulunmuştur.

Giyim eşyası ihracatı denkleminde, giyim eşyası ihracatı dışında, sektöre ilişkin ihracat birim değer endeksi içsel değişken olarak tespit edilmiştir. Giyim Eşyası ihracatı denkleminde yer alan ticaret ortaklarının GSYH'sı, birim işgücü maliyeti ve kullanıcı sektör pozisyonunda bulunan tekstil ürünleri ihracatı değişkeni dışsal olarak bulunmuştur.

Ana metal sektörü ihracatı denkleminde, ana metal ihracatı dışında, kullanıcı sektör pozisyonunda bulunan motorlu kara taşıtları sektörü sanayi üretimi değişkeni de içsel olduğu tespit edilmiştir. Ana metal ihracatı denkleminde yer alan ticaret ortaklarının GSYH'sı, ve sektörel ihracat birim fiyatlarının zayıf dışsallık testine göre dışsal olduğu tespit edilmiştir.

Motorlu kara taşıtları ihracatı denkleminde, motorlu kara taşıtları ihracatı dışında, birim işgücü maliyeti'nin içsel bulunduğu görülmüştür. Denklemde kullanılan diğer bağımsız değişkenlerin dışsal olduğu tespit edilmiştir.

Yukarıda açıklandığı üzere, VEC Modelleri’nde birden fazla içsel değişken bulunmuştur. Ancak çalışmanın konusu itibari ile VEC denkleminin sadece incelenen sektörlerin ihracatına ilişkin kısmı raporlanmıştır. VEC denklemlerinin tamamı yazarlardan alınabilir.

Kurulan VEC Modelleri'nde gecikme sayıları, Autocorrelation LM testine (Johansen, 1995) göre, otokorelasyon sorununun elimine edildiği gecikme sayısı dikkate alınarak belirlenmiştir. 
Tablo: 9

\section{Hata Düzeltme Modelleri Sonuçları}

\begin{tabular}{|c|c|c|c|}
\hline \multicolumn{4}{|c|}{ Hata Düzeltme Modeli Sonuçları -27. Sektör Ana Metal Sanayi } \\
\hline Değlșkenler & Katsayılar & Standart Hata & t dešerlerl \\
\hline DLOG(IHRACAT27(-1)) & $-0,329$ & 0,101 & 3,251 \\
\hline DLOG(IHRACAT27(-2)) & $-0,146$ & 0,117 & $-1,250$ \\
\hline DLOG(IHRACAT27(-3)) & $-0,092$ & 0,107 & $-0,865$ \\
\hline DLOG(IHRACAT27(-4)) & $-0,017$ & 0,112 & $-0,157$ \\
\hline DLOG(SANURET34(-1)) & 0,22 & 0,116 & 1,928 \\
\hline DLOG(SANURET34(-2)) & 0,10 & 0,111 & 0,923 \\
\hline DLOG(SANURET34(-3)) & $-0,17$ & 0,101 & $-1,704$ \\
\hline DLOG(SANURET34(-4)) & 0,045 & 0,104 & 0,434 \\
\hline$c$ & 0,135 & 0,04 & 3,38 \\
\hline DLOG(GDPTICORTAK27) & $-1,112$ & 0,726 & $-1,531$ \\
\hline DLOG(GDPTICORTAK27(-1)) & $-3,569$ & 0,796 & $-4,480$ \\
\hline DLOG(G DPTICORTAK27(-2)) & $-2,148$ & 0,93 & $-2,310$ \\
\hline DLOG(IHRACATBIRIMDEG27) & 1,364 & 0,224 & 6,073 \\
\hline Q3 MEVS. KUKLASI & $-0,208$ & 0,074 & $-2,812$ \\
\hline Q2 MEVS. KUKLASI & $-0,054$ & 0,068 & $-0,795$ \\
\hline RESIDFMOLS(-1) & $-0,881$ & 0,154 & $-5,687$ \\
\hline \multicolumn{4}{|c|}{ Hata Düzeltme Modeli Sonuçları -34. Sektör Motorlu Kara Taşıtları } \\
\hline Deělișenler & Katsayılar & Standart Hata & t dë̆erlerl \\
\hline DLOG(IHRACAT34(-1)) & $-0,081$ & 0,144 & $-0,566$ \\
\hline DLOG(ÍHRACAT34(-2)) & 0,082 & 0,145 & 0,566 \\
\hline DLOG(BIRIMISGUCUMALI(-1)) & 0,645 & 0,373 & 1,728 \\
\hline DLOG(BIRIMISGUCUMALI(-2)) & $-0,075$ & 0,363 & $-0,206$ \\
\hline DLOG(CELIKFIYAT(-1)) & $-0,002$ & 0,002 & $-1,186$ \\
\hline DLOG(CELIKFIYAT(-2)) & $-0,002$ & 0,002 & $-0,881$ \\
\hline c & $-0,020$ & 0,030 & $-0,936$ \\
\hline Q1 MEVS. KUKLASI & 0,136 & 0,062 & 2,181 \\
\hline Q2 MEVS. KUKLASI & 0,120 & 0,050 & 2,402 \\
\hline RESIDFMOLS(-1) & $-0,245$ & 0,143 & $-1,71$ \\
\hline DLOG(GDPTICORTAK34) & 2,852 & 1,652 & 1,725 \\
\hline DLOG(IHRBRIMDEGER34) & 1,667 & 0,455 & 3,660 \\
\hline \multicolumn{4}{|c|}{ Hata Düzeltme Modeli Sonuçlan -17. Sektör Tekstil Ürünleri } \\
\hline Değlșkenler & Katsayılar & Standart Hata & t değerlerl \\
\hline DLOG(IHRACAT17(-1)) & 0,027 & 0,119 & 0,232 \\
\hline DLOG(IHRACAT17(-2)) & 0,268 & 0,110 & $-2,413$ \\
\hline DLOG(SANURET18(-1)) & $-0,047$ & 0,186 & $-0,252$ \\
\hline DLOG(SANURET18(-2)) & $-0,133$ & 0,172 & $-0,777$ \\
\hline c & 0,032 & 0,017 & 1,791 \\
\hline KR/Z2009 & $-0,035$ & 0,049 & $-0,719$ \\
\hline DLOG(GDPTICORTAK17) & $-0,899$ & 1,467 & $-0,613$ \\
\hline DLOG(PARITE) & 0,799 & 0,246 & 3,243 \\
\hline DLOG(SANURET17) & 0,744 & 0,155 & 4,804 \\
\hline RESIDFMOLS(-1) & $-0,575$ & 0,203 & $-2,827$ \\
\hline \multicolumn{4}{|c|}{ Hata Düzeltme Modeli Sonuçları -18. Sektör Giyim Eşyası } \\
\hline Değlșkenler & Katsayılar & Standart Hata & t değerlerl \\
\hline DLOG(IHRACAT18(-1)) & $-0,337$ & 0,170 & $-1,980$ \\
\hline DLOG(IHRACAT18(-2)) & 0,355 & 0,197 & 1,799 \\
\hline DLOG(IHRACAT18(-3)) & 0,107 & 0,167 & 0,639 \\
\hline DLOG(IHRACATBIRIMDEG (-1)) & 0,611 & 0,275 & 2,218 \\
\hline DLOG(IHRACATBIRIMDEG(-2)) & $-0,834$ & 0,329 & $-2,532$ \\
\hline DLOG(IHRACATBIRIMDEG(-3)) & $-0,557$ & 0,219 & $-2,545$ \\
\hline C & 0,000 & 0,017 & 0,007 \\
\hline KRIZ2009 & $-0,098$ & 0,047 & $-2,064$ \\
\hline QS MEVS. KUKLASI & 0,061 & 0,051 & 1,174 \\
\hline DLOG(GDPTICORTAK18) & 1,752 & 1,765 & 0,992 \\
\hline DLOG(BIRIMISGUCUMAL|18) & 0,177 & 0,254 & 0,697 \\
\hline DLOG(BIRIMISGUCUMALI8(-2)) & 0,554 & 0,265 & 2,088 \\
\hline DLOG(IHRACAT17) & $-0,170$ & 0,122 & $-1,384$ \\
\hline RESIDFMOLS(-2) & $-0,516$ & 0,271 & $-1,903$ \\
\hline
\end{tabular}


VEC modeli sonuçları Tablo: 9'da sunulmaktadır. Tüm sektörlere ilişkin uyarlama katsayıları (adjustment coefficient) negatif ve istatistiksel olarak anlamlıdır. $\mathrm{Bu}$ sonuç kurulan Hata Düzeltme Modellerinin geçerliliğini ortaya koymaktadır. Diğer bir ifadeyle, değişkenler arasındaki eşbütünleşme ilişkisinin varlığı doğrulanmaktadır. Kurulan modellerde yer alan değişkenlere beklenmeyen bir şok gelmesi durumunda, incelenen sektörlere ilişkin ihracat uzun dönemde dengeye gelecektir. Ana metal sanayi sektörünün ihracatını belirleyen değişkenlerden herhangi birisine şok gelmesi durumunda yaklaşık bir dönem (çeyrek) sonra ihracat tekrar dengeye gelmektedir. Tekstil ürünlerinde bu süre iki dönemdir (çeyrek). Motorlu kara taşıtları ihracatını belirleyen herhangi bir değişkene gelecek bir şokun etkisini kaybetmesi ve motorlu kara taşıtları ihracatının dengeye gelmesi için ise ortalama 4 dönem (çeyrek) geçmesi beklenmektedir.

Kısa dönemli etkiler incelendiğinde, kısa dönemde dış talebin motorlu kara taşıtları hariç incelenen sektörlerin ihracatı üzerinde istatistiksel olarak anlamlı artırıcı etkisinin bulunmadığı görülmektedir. Diğer taraftan uzun dönemde oldukça güçlü pozitif bir etkinin ortaya çıktı̆̆ bir önceki bölümde izah edilmişti. Birim işgücü maliyetlerinin de motorlu kara taşıtları hariç kısa dönemde sektörlerin ihracatı üzerinde istatistiksel olarak anlamlı bir etkisi yoktur.

İhracat birim değer endeksinin, kısa dönemde motorlu kara taşıtları ve ana metal sanayi sektörü ihracatı üzerinde etkisi pozitif ve anlamlı bulunmuştur. Giyim sektöründe ise etkinin 1. Gecikmede pozitif ve 2 . ve 3 . gecikmede negatif anlamlı olduğu görülmektedir. Ancak, FMOLS modelinde görüldüğü gibi, etki uzun dönemde pozitife dönmektedir.

Bazı denklemlerde dışsal değişkenlerin birinci farklarının bir veya iki gecikmeli değerleri denklemdeki otokorelasyon sorununu gidermek için eklenmiş olup, katsayılarını yorumlamanın anlamlı olmadığı düşünülmektedir.

Özetle, VEC modellerinden elde edilen sonuçlar, motorlu kara taşıtları dışındaki sektörlerde çoğunlukla bağımsız değişkenlerdeki değişimlerin etkilerinin kısa dönemde ortaya çıkmadığını, etkilerin görülmesinin uzun döneme yayıldığını göstermektedir. Kısa dönemde de etkili olan az sayıda değişken bulunmaktadır. Bu durum, ihracatı azaltıcı yönde etkileyecek değişimlerin ortaya çıkması durumunda politika müdahalesi için zaman olduğunu göstermektedir.

\section{Değerlendirme ve Sonuç}

Bu çalışmada Türkiye'nin ihracatı sektörler bazında analiz edilmiştir. ISIC Rev. 3 iki basamaklı bazda 22 imalat sanayi sektöründen 2011 y1lı itibariyle en çok ihracatı yapılan ilk 4'ünün 1998Ç1-2012Ç1 dönemi arasında çeyrekler itibariyle FMOLS ve VEC denklemleri kurularak değişkenler arasındaki uzun dönemli ve kısa dönemli ilişkiler araştırılmıştır. 
Türkiye'nin dışa açılmaya başladığı 1980 yılından bu yana sanayi ürünlerinin toplam ihracat içindeki payı \%36'dan \%93,4'e çıkmıştır. İhracatın yapısı da katma değeri düşük ürünlerden katma değeri yüksek ürünlere doğru değişmiştir. 2011 y1lı itibariyle en çok ihracatı yapılan sektör ana metal sanayidir. Bu sektörü motorlu kara taşıtları ve römorklar izlemektedir. Tekstil ürünleri ve giyim eşyaları sektörleri toplam ihracatta sırasıyla üçüncülüğü ve dördüncülüğü paylaşmaktadır.

Regresyon sonuçları incelendiğinde, uzun dönemde, bütün sektörlerin ihracatı üzerinde diş talebin çok önemli bir etkisinin olduğu görülmektedir. İhracat birim değer endeksinin artması, tekstil hariç incelenen bütün sektörlerde ihracatı artırıcı bir faktördür. Diğer taraftan, birim işgücü maliyetlerinin artmasıyla birlikte, giyim eşyası ve motorlu kara taşıtları sektörlerinin ihracatı uzun dönemde olumsuz olarak etkilenmektedir; diğer sektörlerde istatistiksel açıdan anlamlı bir etki bulunamamıştır. Uzun dönemde kapasite artırımları ve paritede meydana gelecek yukarı yönlü hareketlerin sadece tekstil ürünleri sektörü ihracatını artırması beklenmektedir. Yine, reel kurun değerlenmesi sadece tekstil sektörü ihracatını olumsuz etkilemektedir. $\mathrm{Bu}$ durumun tekstil sektörü için fiyat rekabetinin önemli olmasından kaynaklandığı düşünülmektedir.

Kısa dönemli etkiler incelendiğinde ise, değişkenlerin çoğunun anlamlıllğını yitirdiği görülmektedir. Bu durum, ihracatı etkileyen değişkenlere gelen şokların ihracatı hemen etkilemediği, etkilerin uzun döneme yayıldı̆̆ şeklinde yorumlanabilir.

\section{Kaynakça}

Achy, L. \& K. Sekkat (2003), “The European Single Currency and MENA's Exports to Europe, Review of Development Economics, 7(4), 563-582.

Akal, M. (2008), "Estimating Manufacturing Trade Structures and Elasticities In Turkey: An Inductive Approach", Journal of Economic Cooperation, 29 (3), 49-78.

Altıntaş, H. \& R. Çetin \& B. Öz (2011), "The Impact of Exchange Rate Volatility on Turkish Exports: 1993-2009", The South East European Journal of Economics and Business, 6(2), 67-78.

Arize, A. (1987), “The Supply and Demand for Imports and Exports in a Simultaneous Model”, Applied Economics, 19, 1233-1247.

Aslan, İ \& S. Wijnbergen (1993)," Export Incentives, Exchane Rate Policy and Export Growth in Turkey", the Review of Economics and Statistics, 75(1), 128-133.

Atıcı, C. \& G. Armağan \& R. Tunalığlu \& G. Çinar (2011), "Does Turkey's Integration Into the European Union Boost Its Agricultural Exports?”, Agribusiness, 27 (3) 280-291.

Aydın, M.F. \& U. Çıplak \& M.E. Yücel (2004), "Export Supply and Import Demand Models for the Turkish Economy”, TCMB Çalışma Kâğıdl, 04/09. 
Bonnal, M. (2010), "Export Performance, Labor Standards and Institutions: Evidence from a Dynamic Panel Data Model", J Labor Res, Vol. 31, pp. 53-66.

Bourdon, H.M. \& J. Korinek (2011), "To What Extent Do Exchange Rates and their Volatility Affect Trade?”, OECD Trade Policy Working Papers, No. 119.

Coşar, E.E. (2002), "Price and Income Elasticities of Turkish Export Demand: A Panel Data Application", Central Bank Review, 2, 19-53.

Dinçer, N. \& M. Kandil (2011), "The Effects of Exchange Rate Fluctuations on Exports: A Sectoral Analysis for Turkey”, The Journal of International Trade \& Economic Development: An International and Comparative Review, 20(6), 809-837.

Değer M.K. \& M.C. Genç (2010), “The Impact of Export Market Diversification On Total Exports And Gross Domestic Product: The Cointegration And Causality Tests On Turkish Economy (1980-2007)", Akdeniz İ.̇.B.F. Dergisi, (20), 66-85.

Demirel, B. \& C. Erdem (2004), "Doviz Kurlarındaki Dalgalanmaların İhracata Etkileri: Türkiye Örneği”, Iktisat Isletme ve Finans, 19(223), 116-127.

Égert, B. \& A. Morales-Zumaquero, (2008), "Exchange Rate Regimes, Foreign Exchange Volatility, and Export Performance in Central and Eastern Europe: Just another Blur Project?", Review of Development Economics, 12(3), 577-593.

Elliot, G. \& T.J. Rothenberg \& J.H. Stock (1996), "Efficient Tests for an Autoregressive Unit Root," Econometrica, 64, 813-836.

Jassaud, J. \& S. Rey (2009), "Long-Run Determinants of Japanese Exports to China and the United States: A Sectoral Analysis", Université de Pau et des Pays de l'Adour, Working Paper Series, CATT WP No. 4.

Johansen, S. (1991), "Estimation and Hypothesis Testing of Cointegration Vectors in Gaussian Vector Autoregressive Models", Econometrica, 59, 1551-1580.

Johansen, S. (1995), Likelihood-based Inference In Cointegrated Vector Autoregressive Models, Oxford University Press, Oxford.

Goldstein, M. \& M.S. Khan (1985), "Income and Price Effects in Foreign Trade", in Handbook of International Economics, Vol II: 1041-1105, eds. R.W. Jones and P.B. Kenen, Elsevier Science Publishers B.V.

Harb, N. (2007), "Trade Between Euro Zone and Arab Countries: a Panel Study", Applied Economics, 39, 2099-2107.

King, A. (1997), "From Demand Equations to Two Regimes: The Theoretical Development of Export Models", Bulletin of Economic Research, 49(2), 81-125.

Koççat, H. (2008), "Exchange Rates, Exports and Economic Growth in Turkey: Evidence From Johansen Cointegration Tests", International Journal of Economic Perspectives, 2(1), 511.

Kumar, S. (2009), “An Empirical Evaluation of Export Demand in China”, Journal of Chinese Economic and Foreign Trade Studies, 2(2), 100-109. 
Kwiatkowski, D. \& P.C.B. Phillips \& P. Schmidt \& Y. Shin (1992), “Testing The Null Hypothesis of Stationarity Against The Alternative of a Unit Root: How Sure Are We That Economic Time Series Have A Unit Root?", Journal of Econometrics, 54, 159-178.

Lehman, N. \& D. Herzer \& M.I. Martinez-Zarzoso \& S. Vollmer (2007), The Impact of a Customs Union Between Turkey and the EU on Turkey's Exports to the EU, Journal of Common Market Studies, 45(3), 719-743.

Mah, J. (2007), "The Effect of Duty Drawback on Export Promotion: The Case of Korea”, Journal of Asian Economics, 18, 967-973.

Máñez, J.A. \& J.A. Sanchis Llopis \& M.E. Rochina (2004), "Sunk Costs Hysteresis In Spanish Manufacturing Exports," Working Papers Series EC 2004-17, Instituto Valenciano de Investigaciones Económicas, S.A.

Özkaya, H. (2011), “Effect of Bilateral and Multilateral Agreements on Turkey’s Export”, Doğuş Üniversitesi Dergisi, 12 (2), 279-288.

Özler, Ş. \& E. Taymaz \& K. Yılmaz (2009), "History Matters for the Export Decision: Plant-Level Evidence from Turkish Manufacturing Industry, World Development, 37(2), 479-488.

Peseran, M. \& Y. Shin \& R. Smith (1999), Pooled Mean Group Estimation of Dynamic Heterogenous Panels, Journal of American Statistical Assosiation, 94, 621-634.

Phillips, P.C.B. \& B. Hansen, (1990), "Statistical Inference in Instrumental Variables Regression with I(1) Processes”, Review of Economic Studies, 57, 99-125.

Phillips, P.C.B \& P. Perron (1988), “Testing for a Unit Root in Time Series Regression”, Biometrika, 75, 335-346.

Pineres, S.A.G. \& M.C. Jordá (2010), "Short-Run Effects of Devaluation: A Disaggregated Analysis of Latin American Exports", Applied Economics, 42, 133-142.

Rodriguez, G. \& Y. Samy (2003), "Analysing the Effects of Labour Standards on US Export Performance. A Time Series Approach with Structural Change”, Applied Economics, 2003, 35, 1043-1051.

Saatçioğlu, C. \& O. Karaca (2010), “Dolar/Euro Paritesinin Türkiye’nin İhracatina Etkisi: Ekonometrik Bir Analiz”, Niğde Üniversitesi İ.I.B.F Dergisi, 3(2), 106-118.

Sahinbeyoglu, G. \& B. Ulasan (1999), “An Empirical Examination of the Structural Stability of Export Function”, TCMB Tartışma Kâğıdı, No. 9907.

Sarıkaya, Ç. (2004), "Export Dynamics in Turkey”, Central Bank Review, 2, 41-64.

Saygilı, H. (2010), "Sectoral Export Dynamics of Turkey: A Panel Co-Integration Analysis", Empirical Economics, 38, 373-384.

Rahmaddi, R. \& M. Ichihashi (2012), "How Do Foreign and Domestic Demand Affect Exports Performance? An Econometric Investigation of Indonesia's Exports", Modern Economy, No. 3, 32-42.

Senhadji, A. \& C. Montenegro (1998), “Time Series Analysis of Export Demand Equations: A Cross Country Analysis", IMF Working Papers, WP/98/149. 
Seymen, D. \& U. Utkulu (2004), “Trade and Competitiveness Between Turkey and the EU: Time Series Evidence, Türk Ekonomi Kurumu Tartışma Kâğıdı, 2004/8.

Solakoğlu, M.N. (2010), "Exchange Rate Exposure and Real Exports", Applied Economics Letters, $17,457-462$.

Uygur, E. (1997), "Export Policies and Export Performance: The Case of Turkey", ERF Working Paper Series, 199707.

Uz, İ. (2010), "Testing for Structural Change in the Bilateral Trade Elasticities of Turkey", METU Studies in Development, 37, 53-72.

Vergil, H. (2002), "Exchange Rate Volatility in Turkey and Its Effect on Trade Flows, Journal of Economic and Social Research, 4(1), 83-99.

Vergil, H. (2010), “Türkiye Ticaretinde Ulusal Pazar Etkisi”, İktisat, İşletme ve Finans, 25(286), 3559.

Vural, Y.İ. \& M. Zortuk (2011), “Foreign Direct Investment as a Determining Factor in Turkey’s Export Performance", Eurasian Journal of Business and Economics, 2011, 4 (7), 13-23.

Warner, D. \& M.E. Kreinin, (1983), "Determinants of International Trade Flows”, The Review of Economics and Statistics, 65, 96-104.

Yalçınkaya, M.H. \& C. Çılbant \& M. Özçalık (2009), “Avrupa Birliği Sürecinde Türk İmalat Sanayi Diş Ticaretinin Rekabet Gücü: 1898-2009 Dönemi VAR Analizi”, Yönetim ve Ekonomi, 16(1), 116-137.

Yılmaz, O, \& V. Kaya (2007), "İhracat, İthalat ve Reel Doviz Kuru İlişkisi: Turkiye İçin Bir VAR Modeli”, Iktisat Isletme ve Finans, 22(250), 69-84.

Yurtkur, A. K. \& A.T. Bayramoğlu (2012), "Export Dynamics in Emerging Market Economies”, Yönetim ve Ekonomi, 19(1), 19-33. 
Ek: 1

Literatür Taraması

\begin{tabular}{|c|c|c|c|c|c|}
\hline Yazarlar & Dönem & $\ddot{~ U ̈ l k e l e r ~}$ & Bağımsız Değişken & Yöntem & Bağımsız Değişkenler ve Sonuçlar \\
\hline $\begin{array}{l}\text { Aydın vd. } \\
(2004)\end{array}$ & 1987Ç1-2003Ç4 & Türkiye & İhracat miktar endeksleri & $\begin{array}{l}\text { Engle-Granger, } \\
\text { ECM ve VAR }\end{array}$ & $\begin{array}{l}\text { Reel milli gelir (+), reel kur (0), ihraç fiyatları (-), birim iş gücü } \\
\text { maliyetleri (-) }\end{array}$ \\
\hline $\begin{array}{l}\text { Sarkaya } \\
(2004)\end{array}$ & 1989Ç1-2003Ç3 & Türkiye & Reel ihracat & SVAR, ARDL & Reel gelir $(+)$, reel kur $(-)$, ve reel birim ücretler (-) \\
\hline Harb (2007) & $1976-2003$ & $\begin{array}{l}15 \text { Arab ülkesinin } \\
\text { Avro Bölgesine } \\
\text { ihracatı }\end{array}$ & Reel ihracat & $\begin{array}{l}\text { Panel ve indiv. } \\
\text { ülkeler zaman } \\
\text { serisi DOLS, } \\
\text { FMOLS }\end{array}$ & Reel dış gelir $(+/ 0)$, göreli fiyatlar $(+)$ \\
\hline $\begin{array}{l}\text { Altıntaş vd. } \\
(2011)\end{array}$ & 1993Ç3-2009Ç4 & Türkiye & İhracat/GSYH & ARDL, ECM & $\begin{array}{l}\text { Reel dış gelir (+), göreli fiyatlar (Türkiye ihraç fiyatları/dünya } \\
\text { ihraç fiyatları) }(0) \text {, kur değişkenliği }(+)\end{array}$ \\
\hline $\begin{array}{l}\text { Rahmaddi ve } \\
\text { Ichihashi } \\
\text { (2012) }\end{array}$ & $1971-2007$ & Endonezya & $\begin{array}{l}\text { İhracat talebi ve ihracat } \\
\text { fiyatları (ihracat arz modeli) } \\
\text { (eşanlı) } \\
\end{array}$ & $\begin{array}{l}\text { Eşanlı denklem } \\
\text { sistemi-2SLS }\end{array}$ & $\begin{array}{l}\text { İhracat talebi denklemi: göreli fiyatlar (yerel/dış) (-) diş dönemsel } \\
\text { (cyclical) gelir }(0) \text { dış trend gelir (+), Fiyat denklemi: yerel } \\
\text { dönemsel gelir }(+) \text {, yerel trend gelir }(-) \text {, yerel fiyatlar }(+)\end{array}$ \\
\hline $\begin{array}{l}\text { Bourdon ve } \\
\text { Korinek } \\
(2011)\end{array}$ & 1999m1-2009m6 & $\begin{array}{l}\text { Avro alanı, ABD ve } \\
\text { Çin arasında ikili } \\
\text { ticaret } \\
\end{array}$ & $\begin{array}{l}\text { Tarım ve imalat sanayi } \\
\text { ürünleri ihracat değeri }\end{array}$ & ARDL & $\begin{array}{l}\text { Reel dış gelir (sanayi üretim endeksi)(+), reel kur ((-) Avrupa'dan } \\
\text { Çin'e tarım ürünleri ihracatı hariç)), kur değişkenliği (karışık- } \\
\text { sektörel seviyede asgari etki) }\end{array}$ \\
\hline $\begin{array}{l}\text { Jaussaud ve } \\
\text { Rey (2009) }\end{array}$ & $1971-2007$ & $\begin{array}{l}\text { Japonya'nın Çin ve } \\
\text { ABD'ye ihracatı }\end{array}$ & \begin{tabular}{|l|} 
Japonya'nın Çin ve ABD'ye \\
6 sanayi sektöründe reel \\
ihracatı \\
\end{tabular} & $\begin{array}{l}\text { VEC } 6 \text { sektör ve } \\
\text { ülkeler farklı } \\
\text { denklemlerde }\end{array}$ & $\begin{array}{l}\text { Reel dış gelir (+), ikili reel kur (-), kur değiş̧kenliği (-) bazı } \\
\text { değişkenlerde bazı istisnalarla }\end{array}$ \\
\hline $\begin{array}{l}\text { Rodriguez ve } \\
\text { Samy (2003) }\end{array}$ & $1950-1998$ & $\mathrm{ABD}$ & İhracat/GSYH & $\begin{array}{l}\text { Zaman serisi } \\
\text { (yapısal } \\
\text { kırılmalarla) }\end{array}$ & $\begin{array}{l}\text { Çalışılan saat, iş kazalarının sayısı (+), sendikalaşma oranı (-), reel } \\
\text { faiz oranı (borç verme oranı-TÜFE) }\end{array}$ \\
\hline $\begin{array}{l}\text { Lehman vd. } \\
(2007)\end{array}$ & $1988-2002$ & $\begin{array}{l}\text { Türkiye'nin } \mathrm{AB} \\
\text { ülkelerine ihracatı }\end{array}$ & $\begin{array}{l}\text { Türkiye'nin } 16 \text { HS } \\
\text { sektöründe AB ülkelerine } \\
\text { ihracatı }\end{array}$ & Panel-yerçekimi & $\begin{array}{l}\text { Ticaret ortağının reel geliri (+), ticaret ortaklarının kişi başı } \\
\text { gelirlerinin farlı (karışı), reel kur (sektöre özgü korumaları göz } \\
\text { önünde bulundurarak hesaplanmış)(-), Türkiye'nin AB dışı } \\
\text { rakiplerinin reel kuru (-), taşımacılık maliyetleri (+/0), ana rakiple } \\
\text { taşımacılık maliyetleri farkı (karışı) }\end{array}$ \\
\hline $\begin{array}{l}\text { Egert ve } \\
\text { Zurnaquero } \\
(2008)\end{array}$ & $1990-2003$ & $\begin{array}{l}\text { Çek Cumh. } \\
\text { Macaristan, } \\
\text { Polonya, Romanya, } \\
\text { Rusya, Hırvatistan, } \\
\text { Slovakya, Slovenya }\end{array}$ & $\begin{array}{l}\text { Toplam nominal ihracat ve } \\
\text { reel ihracat iki farklı } \\
\text { denklemde. Ayrıca } 5 \\
\text { sektörel ihracat denklemi }\end{array}$ & $\begin{array}{l}\text { Panel-sabit } \\
\text { etkiler ve tek tek } \\
\text { ülkeler zaman } \\
\text { serisi DOLS, } \\
\text { ARDL } \\
\end{array}$ & $\begin{array}{l}\text { Nominal ihracat: nominal yerel gelir/nominal dış gelir (+), yerel } \\
\text { fiyatlar/dış fiyatlar }(0) \text {, nominal kur }(+) \text {, yabancı doğrudan } \\
\text { yatırımlar (karışık), nominal kru değişkenliği (karışı), reel } \\
\text { ihracat: reel yerel/dış gelir }(+) \text {, reel Kur }(+) \text {, yabancı doğrudan } \\
\text { yatırımlar /GSYH (karışı), reel kur değişkenliği (karışık). }\end{array}$ \\
\hline Koççat (2008) & 1980Ç1-2003Ç4 & Türkiye & $\begin{array}{l}\text { İhracat, reel kur, kişi başı } \\
\text { gelir }\end{array}$ & $\begin{array}{l}\text { Johansen } \\
\text { eșbütünleșme }\end{array}$ & Eşbütünleşme ilişkisi bulunamamıştır. \\
\hline
\end{tabular}




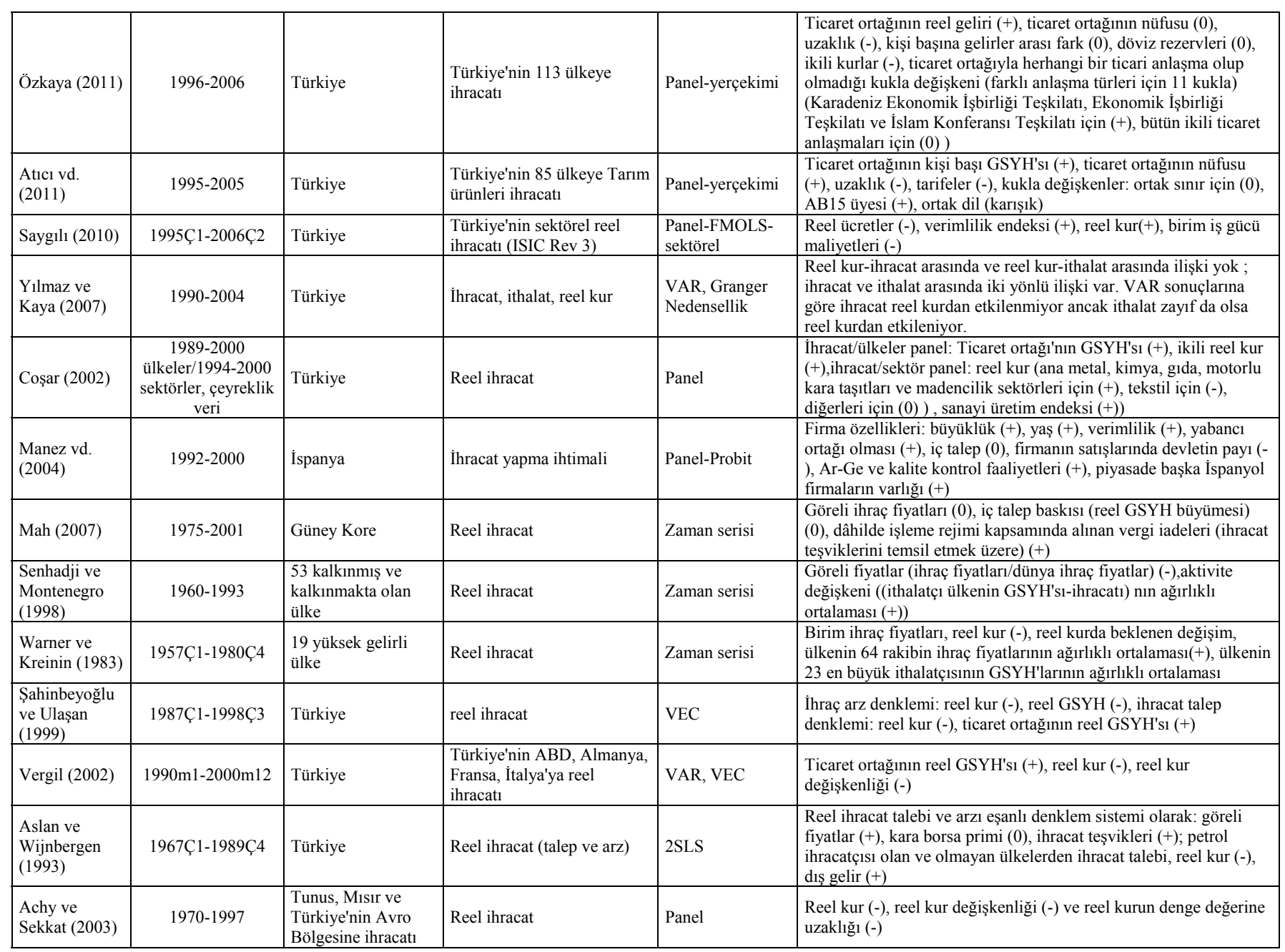




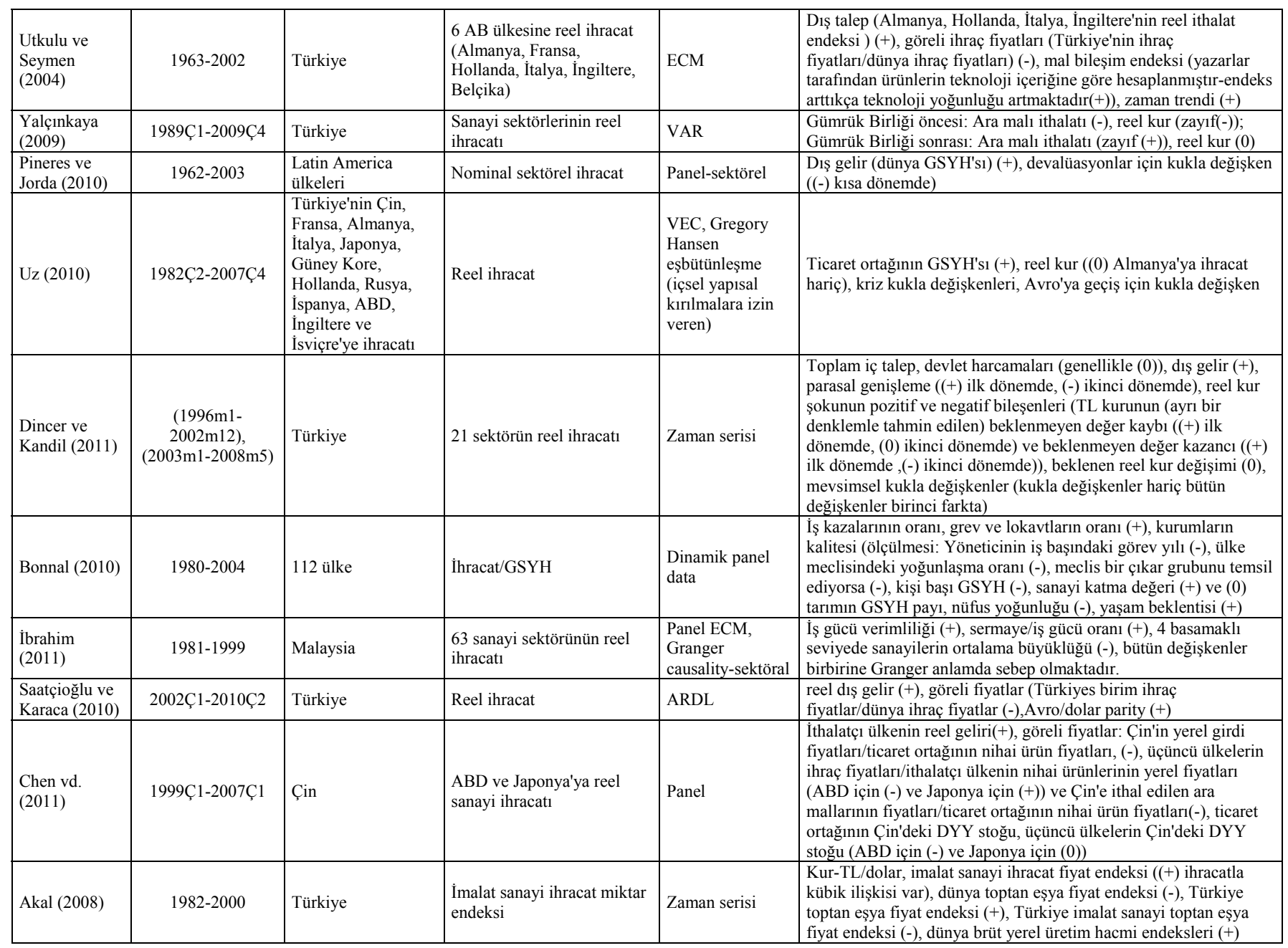




\begin{tabular}{|c|c|c|c|c|c|}
\hline $\begin{array}{l}\text { Yurtkur ve } \\
\text { Bayramoğlu } \\
(2012)\end{array}$ & 1994Ç1-2009Ç1 & $\begin{array}{l}\text { Türkiye, Meksika, } \\
\text { Tayland, G. Kore, } \\
\text { Endonezya, } \\
\text { Malezya, Çin, } \\
\text { Brezilya, Arjantin } \\
\end{array}$ & reel ihracat & Panel & $\begin{array}{l}\text { Yerel GSYH \% değişimi }(+) \text {, enflasyon oranı }(+) \text {, reel efektif kur } \\
(-) \text {, ithalat }(+)\end{array}$ \\
\hline $\begin{array}{l}\text { Solakoğlu } \\
(2010)\end{array}$ & 2001-2003/haftalık & Türkiye & $\begin{array}{l}\text { Firma seviyesinde reel } \\
\text { ihracat }\end{array}$ & Panel & $\begin{array}{l}\text { Sanayileşmiş ülkelerin GSYH'sı, dış/yerel fiyatları, ikili kurlar } \\
\text { (ABD doları ve Avro'nın yerel para cinsinden fiyatı ile ölçülen ), } \\
\text { kur riski ölçütleri (aylık ikili kurların standart sapması (0), firmaya } \\
\text { özgü kur riskine maruz olma ölçütü-ayrı bir modelle tahmin } \\
\text { edilmiş (bağımlı değişken firmanın hisse senedi getirisi ve } \\
\text { bağımsız değişkenler firmanın avro ve dolar portföyü olmak } \\
\text { üzere), Avro/dolar parite riski (-) }\end{array}$ \\
\hline $\begin{array}{l}\text { Değer ve Genç } \\
(2010)\end{array}$ & $1980-2007$ & Türkiye & $\begin{array}{l}\text { Reel ihracat, enthropy } \\
\text { endeksi (azalan değerler } \\
\text { artan coğrafi } \\
\text { konsantrasyona işaret } \\
\text { ediyor), Türkiye'nin } \\
\text { GSYH'sı } \\
\end{array}$ & $\begin{array}{l}\text { Johansen } \\
\text { eşbütünleşme ve } \\
\text { Toda-Yamamoto } \\
\text { nedensellik }\end{array}$ & $\begin{array}{l}\text { Bütün değişkenler arasında iki yönlü nedensellik var, ihracat } \\
\text { pazarlarının artan coğrafi çeşitliliği hem ihracatı ve hem de } \\
\text { GSYH'yı pozitif etkiliyor. }\end{array}$ \\
\hline $\begin{array}{l}\text { Özler vd. } \\
\text { (2009) }\end{array}$ & $1990-2001$ & Türkiye & $\begin{array}{l}\text { Firma seviyesinde veriler- } \\
\text { Bağımlı değişken = } 1 \text { veya } \\
0 \text {, ihracat yapıyor ve } \\
\text { yapmıyorsa, ISIC bazında } \\
28 \text { tane } 3 \text { basamaklı sektör } \\
\text { ve } 12931 \text { fabrika }\end{array}$ & $\begin{array}{l}\text { Panel Logit- } \\
\text { sektörel }\end{array}$ & $\begin{array}{l}\text { Bir veya iki yıldır ihracat yapıyor olma durumu }(+) \text {, fabrika } \\
\text { büyüklüğü, istihdam }(+) \text {, bayan çalışan oranı }(+) \text {, teknik eleman } \\
\text { oranı }(+) \text {, üretimin sermaye yoğunluğu }(+) \text {, ithal edilen makine ve } \\
\text { ekipman }(+) \text {, spillover değişkenleri (sektördeki ihracatçıların } \\
\text { oranı) }(+) \text {, daha uzun ihracat tecrübesine sahip firmaların ihracat } \\
\text { yapmaya devam etme ihtimali daha yüksek, ancak tecrübe azalan } \\
\text { getiriye sahip ve ihracat tecrübesi hızla amortise oluyor. }\end{array}$ \\
\hline Arize (1987) & $1960-1982$ & 8 Afrika ülkesi & Reel ihracat (talep ve arz) & 2SLS & $\begin{array}{l}\text { Talep denklemi: ihracat birim fiyatları/dünya fiyat seviyesi } \\
\text { (karışı, genellikle }(-)) \text {, dünya reel geliri (trend }(+) \text { ve döngüsel }(+) \\
\text { kısımları); Arz denklemi: yerel çıktı (trend }(+) \text { ve döngüsel }(+) \\
\text { kısımları), ihraç fiyatları }(+) \text {, yerel fiyat seviyesi }(+)\end{array}$ \\
\hline $\begin{array}{l}\text { Vural ve } \\
\text { Zortuk (2011) }\end{array}$ & $1982-2009$ & Türkiye & Reel ihracat (talep ve arz) & 3SLS & $\begin{array}{l}\text { Talep denklemi: reel kur (-), dünya reel geliri (+) Arz denklemi: } \\
\text { Türkiye'nin ihraç fiyatları/yerel fiyatlar (+), iç talep baskısı (bütçe } \\
\text { açığı/GSYH) (-), DYY akımları }(+)\end{array}$ \\
\hline Vergil (2010) & 1989-2007 & Türkiye & $\begin{array}{l}\text { Reel ihracat (sektörler-SITC } \\
\text { ve ülkeler) }\end{array}$ & $\begin{array}{l}\text { Panel-Ortalama } \\
\text { Grup }\end{array}$ & $\begin{array}{l}\text { Türkiye'nin GSYH'sı (+), ticaret ortağının GSYH'sı (+) ve AB } \\
\text { ülkeleri için kukla değişken }\end{array}$ \\
\hline
\end{tabular}


EK: 2

ISIC REV. 3 İmalat Sanayi Sektör Tanımları

\begin{tabular}{|c|l|}
\hline ISIC Rev. 3Kodu & \multicolumn{1}{|c|}{ Sektör Adı } \\
\hline 15 & Gıda ürünleri ve içecek \\
\hline 16 & Tütün ürünleri \\
\hline 17 & Tekstil ürünleri \\
\hline 18 & Giyim eşyası \\
\hline 19 & Dabaklanmış deri, bavul, el çantası, saraciye ve ayakkabı \\
\hline 20 & Ağaç ve mantar ürünleri (mobilya hariç); hasır vb. örülerek yapılan maddeler \\
\hline 21 & Kağıt ve kağı ürünleri \\
\hline 22 & Basım ve yayım; plak, kaset vb. \\
\hline 23 & Kok kömürü, rafine edilmiş petrol ürünleri ve nükleer yakıtlar \\
\hline 24 & Kimyasal madde ve ürünler \\
\hline 25 & Plastik ve kauçuk ürünleri \\
\hline 26 & Metalik olmayan diğer mineral ürünler \\
\hline 27 & Ana metal sanayi \\
\hline 28 & Metal eşya sanayi (makine ve teçhizatı hariç) \\
\hline 29 & Başka yerde sınıflandırılmamış makine ve teçhizat \\
\hline 30 & Büro, muhasebe ve bilgi işleme makinaları \\
\hline 31 & Başka yerde sınıflandırılmamış elektrikli makina ve cihazlar \\
\hline 32 & Radyo, televizyon, haberleşme teçhizatı ve cihazları \\
\hline 33 & Tıbbi aletler; hassas optik aletler ve saat \\
\hline 34 & Motorlu kara taşıtı ve römorklar \\
\hline 35 & Diğer ulaşım araçları \\
\hline 36 & Mobilya ve başka yerde sınıflandırılmamış diğer ürünler \\
\hline & \\
\hline
\end{tabular}


EK: 3

BIIRIM KÖK TESTLERI SONUÇLARI

\begin{tabular}{|c|c|c|c|c|c|}
\hline \multirow[b]{2}{*}{ Değişkenler } & \multirow[b]{2}{*}{ ERS Test İstatistiği } & \multicolumn{3}{|c|}{ Kritik Değerler } & \multirow[b]{2}{*}{ Durağanlık Düzeyi } \\
\hline & & $1 \%$ & $5 \%$ & $10 \%$ & \\
\hline Birimisgücmal17 & 12,5102 & 1,87 & 2,98 & 3,94 & \multirow{2}{*}{$\mathrm{I}(1)$} \\
\hline D(Birimisgücmal17) & 1,5645 & 1,87 & 2,98 & 3,94 & \\
\hline Birimisgücmal34 & 10,1179 & 1,87 & 2,98 & 3,94 & \multirow{2}{*}{$\mathrm{I}(1)$} \\
\hline D(Birimisgücmal34) & 3,2101 & 1,87 & 2,98 & 3,94 & \\
\hline gdpticortak17 & 5,6149 & 1,87 & 2,98 & 3,94 & \multirow{2}{*}{$\mathrm{I}(1)$} \\
\hline D(gdpticortak17) & 0,8994 & 1,87 & 2,98 & 3,94 & \\
\hline gdpticortak18 & 98,3527 & 1,87 & 2,98 & 3,94 & \multirow{2}{*}{$I(1)$} \\
\hline D(gdpticortak18) & 3,5766 & 1,87 & 2,98 & 3,94 & \\
\hline gdpticortak27 & 264,8994 & 1,87 & 2,98 & 3,94 & \multirow{2}{*}{$\mathrm{I}(1)$} \\
\hline $\mathrm{D}$ (gdpticortak27) & 0,0783 & 1,87 & 2,98 & 3,94 & \\
\hline gdpticortak34 & 127,933 & 1,87 & 2,98 & 3,94 & \multirow{2}{*}{$\mathrm{I}(1)$} \\
\hline D(gdpticortak34) & 0,9822 & 1,87 & 2,98 & 3,94 & \\
\hline ihracat17 & 27,4427 & 1,87 & 2,98 & 3,94 & \multirow{2}{*}{$\mathrm{I}(1)$} \\
\hline $\mathrm{D}$ (ihracat17) & 0,354 & 1,87 & 2,98 & 3,94 & \\
\hline ihracat18 & 15,2955 & 1,87 & 2,98 & 3,94 & \multirow{2}{*}{$\mathrm{I}(1)$} \\
\hline $\mathrm{D}$ (ihracat18) & 1,2813 & 1,87 & 2,98 & 3,94 & \\
\hline ihracat27 & 59,6002 & 1,87 & 2,98 & 3,94 & \multirow{2}{*}{$\mathrm{I}(1)$} \\
\hline $\mathrm{D}$ (ihracat27) & 1,2707 & 1,87 & 2,98 & 3,94 & \\
\hline ihracat34 & 294,1222 & 1,87 & 2,98 & 3,94 & \multirow{2}{*}{$I(1)$} \\
\hline D(ihracat34) & 1,2100 & 1,87 & 2,98 & 3,94 & \\
\hline ihracatbirimdeger17 & 15,3583 & 1,87 & 2,98 & 3,94 & \multirow{2}{*}{$\mathrm{I}(1)$} \\
\hline D(ihracatbirimdeger17) & 0,5497 & 1,87 & 2,98 & 3,94 & \\
\hline ihracatbirimdeger18 & 12,695 & 1,87 & 2,98 & 3,94 & \multirow{2}{*}{$\mathrm{I}(1)$} \\
\hline D(ihracatbirimdeger18) & 3,4898 & 1,87 & 2,98 & 3,94 & \\
\hline ihracatbirimdeger 27 & 18,7143 & 1,87 & 2,98 & 3,94 & \multirow{2}{*}{$\mathrm{I}(1)$} \\
\hline D(ihracatbirimdeger27) & 1,1408 & 1,87 & 2,98 & 3,94 & \\
\hline ihracatbirimdeger34 & 21,1532 & 1,87 & 2,98 & 3,94 & \multirow{2}{*}{$\mathrm{I}(1)$} \\
\hline D(ihracatbirimdeger34) & 0,7308 & 1,87 & 2,98 & 3,94 & \\
\hline parite & 11,0943 & 1,87 & 2,98 & 3,94 & \multirow{2}{*}{$\mathrm{I}(1)$} \\
\hline $\mathrm{d}$ (parite) & 2,7377 & 1,87 & 2,98 & 3,94 & \\
\hline rkur & 7,7014 & 1,87 & 2,98 & 3,94 & \multirow{2}{*}{$\mathrm{I}(1)$} \\
\hline$d$ (rkur) & 0,5371 & 1,87 & 2,98 & 3,94 & \\
\hline sanuret17 & 5,6654 & 1,87 & 2,98 & 3,94 & \multirow{2}{*}{$\mathrm{I}(1)$} \\
\hline d(Sanuret17) & 1,4794 & 1,87 & 2,98 & 3,94 & \\
\hline sanuret27 & 16,8456 & 1,87 & 2,98 & 3,94 & \multirow{2}{*}{$\mathrm{I}(1)$} \\
\hline d(Sanuret27) & 1,2303 & 1,87 & 2,98 & 3,94 & \\
\hline sanuret34 & 16,9924 & 1,87 & 2,98 & 3,94 & \multirow{2}{*}{$\mathrm{I}(1)$} \\
\hline $\mathrm{d}($ Sanuret34) & 0,2301 & 1,87 & 2,98 & 3,94 & \\
\hline yurticielektrik & 5,6149 & 1,87 & 2,98 & 3,94 & \multirow{2}{*}{$\mathrm{I}(1)$} \\
\hline $\mathrm{d}$ (yurticielektrik) & 0,8994 & 1,87 & 2,98 & 3,94 & \\
\hline
\end{tabular}

